\title{
U.S. Geological Survey Science Strategy for Highly Pathogenic Avian Influenza in Wildlife and the Environment (2016-2020)
}

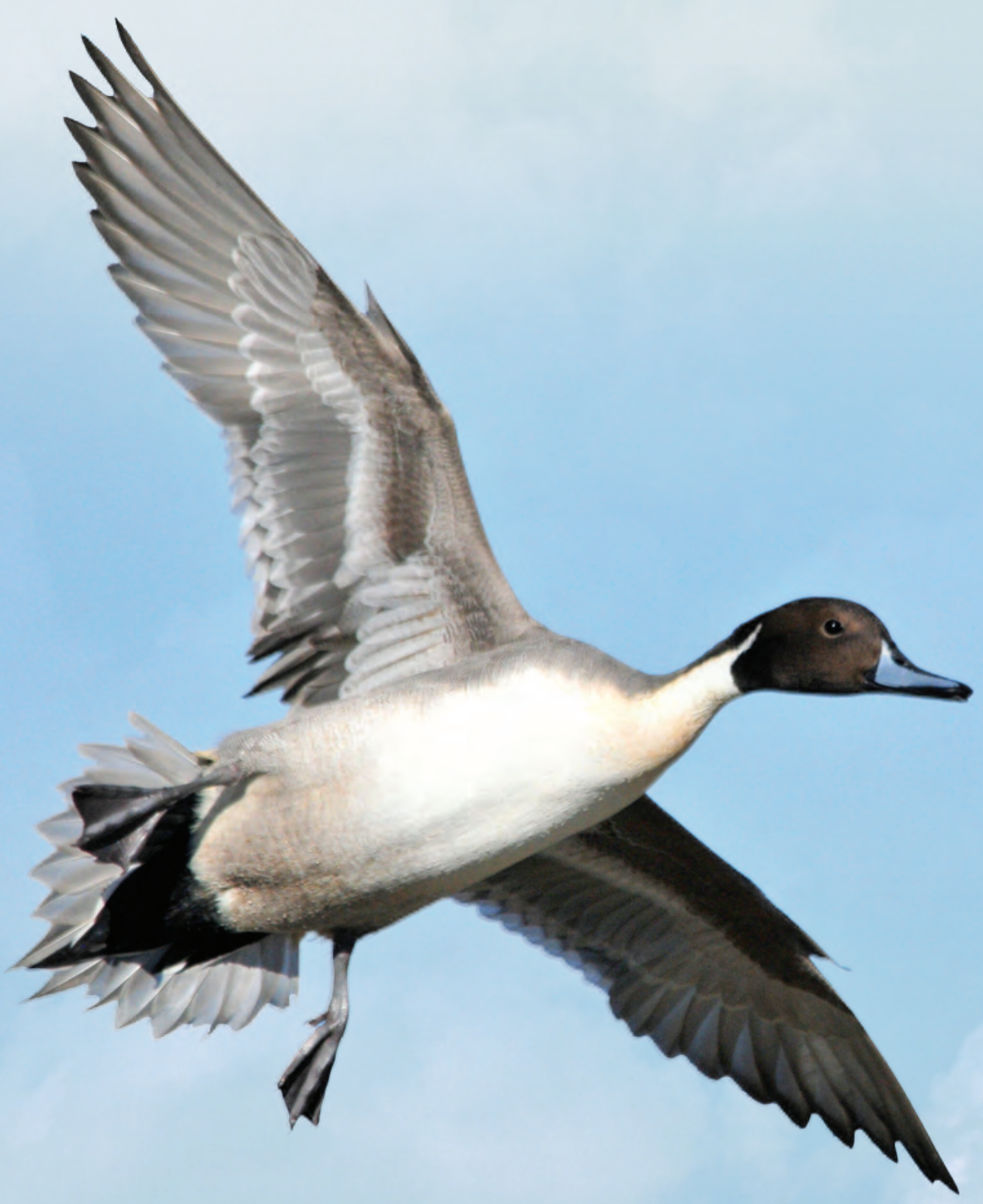

Open-File Report 2016-1121 
Cover. Male Northern Pintail flying above Seedskadee National Wild life Refuge in Wyoming. Photograph by Tom Koerner, U.S. Fish and Wildlife Service. Licensed under Creative Commons Attribution 2.0 Generic license. 


\section{U.S. Geological Survey Science Strategy for Highly Pathogenic Avian Influenza in Wildlife and the Environment (2016-2020)}

By M. Camille Harris, John M. Pearce, Diann J. Prosser, C. LeAnn White, A. Keith Miles, Jonathan M. Sleeman, Christopher J. Brand*, James P. Cronin, Susan De La Cruz, Christine L. Densmore, Thomas W. Doyle, Robert J. Dusek, Joseph P. Fleskes, Paul L. Flint, Gerald F. Guala, Jeffrey S. Hall, Laura E. Hubbard, Randall J. Hunt, Hon S. Ip, Rachel A. Katz, Kevin W. Laurent, Mark P. Miller, Mark D. Munn, Andrew M. Ramey, Kevin D. Richards, Robin E. Russell, Joel P. Stokdyk, John Y. Takekawa, and Daniel P. Walsh

[*authors listed from here forward are in alphabetical order]

Open-File Report 2016-1121 


\title{
U.S. Department of the Interior \\ SALLY JEWELL, Secretary
}

\author{
U.S. Geological Survey \\ Suzette M. Kimball, Director
}

\section{U.S. Geological Survey, Reston, Virginia: 2016}

For more information on the USGS - the Federal source for science about the Earth, its natural and living resources, natural hazards, and the environment-visit http://www.usgs.gov or call 1-888-ASK-USGS.

For an overview of USGS information products, including maps, imagery, and publications,

visit http://store.usgs.gov.

Any use of trade, firm, or product names is for descriptive purposes only and does not imply endorsement by the U.S. Government.

Although this information product, for the most part, is in the public domain, it also may contain copyrighted materials as noted in the text. Permission to reproduce copyrighted items must be secured from the copyright owner.

\section{Suggested citation:}

Harris, M.C., Pearce, J.M., Prosser, D.J., White, C.L., Miles, A.K., Sleeman, J.M., Brand, C.J., Cronin, J.P., De La Cruz, S., Densmore, C.L., Doyle, T.W., Dusek, R.J., Fleskes, J.P., Flint, P.L., Guala, G.F., Hall, J.S., Hubbard, L.E., Hunt, R.J., Ip, H.S., Katz, R.A., Laurent, K.W., Miller, M.P., Munn, M.D., Ramey, A.M., Richards, K.D., Russell, R.E., Stokdyk, J.P., Takekawa, J.Y., and Walsh, D.P., 2016, U.S. Geological Survey science strategy for highly pathogenic avian influenza in wildlife and the environment (2016-2020): U.S. Geological Survey Open-File Report 2016-1121, 38 p., http://dx.doi.org/10.3133/ofr20161121.

ISSN 2331-1258 (online) 


\section{Contents}

Executive Summary

Vision

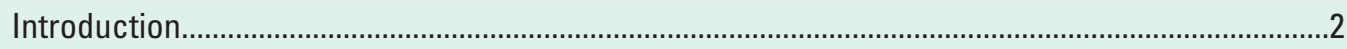

Science Outcomes of the U.S. Geological Survey Science Strategy on HPAI in Wildlife and the Environment.

U.S. Geological Survey HPAI Science Goals .............................................................................

Science Goal 1: Augment National HPAI Surveillance Plan ......................................................

Objective 1. Develop tools and strategies for early HPAI detection in wildlife

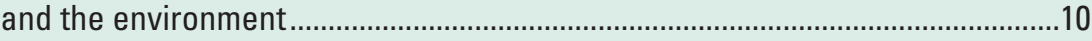

Objective 2. Conduct HPAI surveillance in wild birds and peridomestic wildlife ..........10

Science Goal 2: Determine Mechanisms of HPAI Disease Spread in Wildlife and the

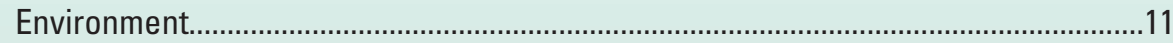

Objective 1. Determine mechanisms of HPAl spread and persistence in wildlife ........11

Objective 2. Determine mechanisms of HPAI spread and persistence in the environment

Objective 3. Determine mechanisms of HPAl spread and persistence in peridomestic wildlife found near poultry operations

Objective 4. Determine implications of LPAI and HPAI exposure for wildlife populations

Science Goal 3: Characterize HPAI Viruses Circulating in Wildlife .....................................14

Objective 1. Characterize Al viruses circulating in wild birds .......................................15

Objective 2. Characterize Al viruses circulating in wild mammals ...............................16

Objective 3. Characterize HPAl viruses circulating outside North America and on the continental fringes with potential for introduction to North America

Science Goal 4: Understand Implications of Avian Ecology on HPAI Spread.........................17

Objective 1. Map spatial and temporal distributions of wild and domestic avian populations for risk model development

Objective 2. Address Al-relevant information gaps in avian migratory connectivity data

Objective 3. Investigate HPAI transmission in avian communities and the impact of HPAI on avian populations ...................................................................19

Science Goal 5: Develop HPAI Forecasting and Decision-Making Tools ................................19

Objective 1. Provide decision support to management agencies ...................................20

Objective 2. Develop HPAl risk assessment and predictive models.............................22

Objective 3. Develop online HPAI data visualization tools ................................................23

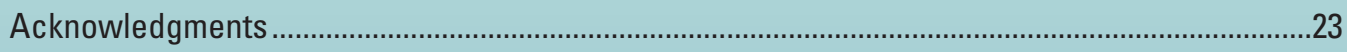

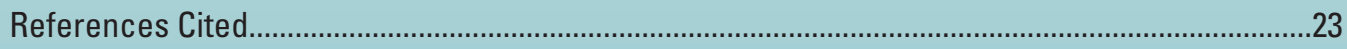

Appendix 1. Overview of U.S. Geological Survey Capabilities for Avian Influenza Research.......34

Integrating HPAI Science Across U.S. Geological Survey Mission Areas ..............................34

Appendix 2. Examples of U.S. Geological Survey Capabilities for Avian Influenza Research........36

Genetic and Stable Isotope Analysis of Wildlife Populations .................................................36

Telemetry Movement Studies of Wildlife Populations.................................................................36

Disease Risk Modeling............................................................................................................. 


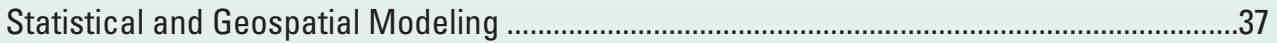

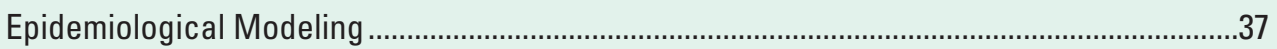

Laboratory and Experimental Animal Studies on Diseases.....................................................37

Decision Science and Data Visualization Tools......................................................................38

Virus Detection in the Aquatic Environment ………...............................................................38

\section{Figures}

1. Conceptual model of the process of introduction and wild bird dispersal of Al and subsequent infection of commercial poultry holdings

2. Diagram showing the U.S. Geological Survey Science Strategy for HPAI in Wildlife and the Environment is based on the relationship between scientific discovery and the application of new knowledge.

3. Illustration showing the U.S. Geological Survey Science Strategy for HPAI in Wildlife and the Environment (2016-2020) is focused on five long-term science goals

A1-1. Diagram showing the U.S. Geological Survey has considerable scientific capabilities nationwide to study avian influenza

\section{Highlights}

1: What is the Role of the USGS in the Federal Response to HPAI?

2: The Importance of Long-Term Research for Disease Surveillance ..........................................9

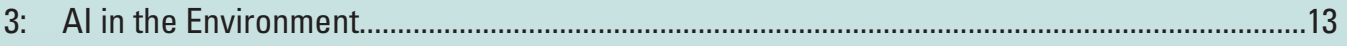

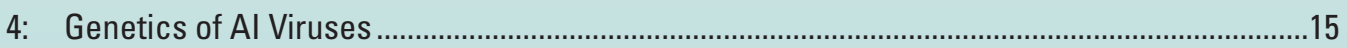

5: Merging Wild Bird Migration and Disease Ecology ............................................................18

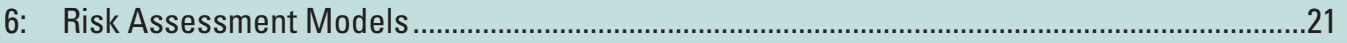




\section{Abbreviations}

Al avian influenza

APHIS USDA Animal and Plant Health Inspection Service

ASC USGS Alaska Science Center

CDC Centers for Disease Control and Prevention

CIDA USGS Office of Water Information Center for Integrated Data

CRU USGS Cooperative Research Unit

DOI U.S. Department of the Interior

FRESC USGS Forest and Rangeland Ecosystem Science Center

GHSA Global Health Security Agenda

GPS global positioning system

HA hemagglutinin

HEDDS USGS Highly Pathogenic Avian Influenza Early Detection Data System

HPAI highly pathogenic avian influenza

icA highly pathogenic avian influenza intercontinental group A viruses

LIDE USGS-USDA Laboratory for Infectious Diseases in the Environment

LPAI low pathogenic avian influenza

NA neuraminidase

NOROCK Northern Rocky Mountain Science Center

NWHC USGS National Wildlife Health Center

OIE Office International des Epizooties (World Organization for Animal Health)

PWRC USGS Patuxent Wildlife Research Center

qPCR quantitative polymerase chain reaction

UMESC USGS Upper Midwest Environmental Science Center

U.S. United States

USDA U.S. Department of Agriculture

USFWS U.S. Fish and Wildlife Service

USGS U.S. Geological Survey

WARC USGS Wetland and Aquatic Research Center

WERC USGS Western Ecological Research Center

WHISPers USGS Wildlife Health Information Sharing Partnership—event reporting system 

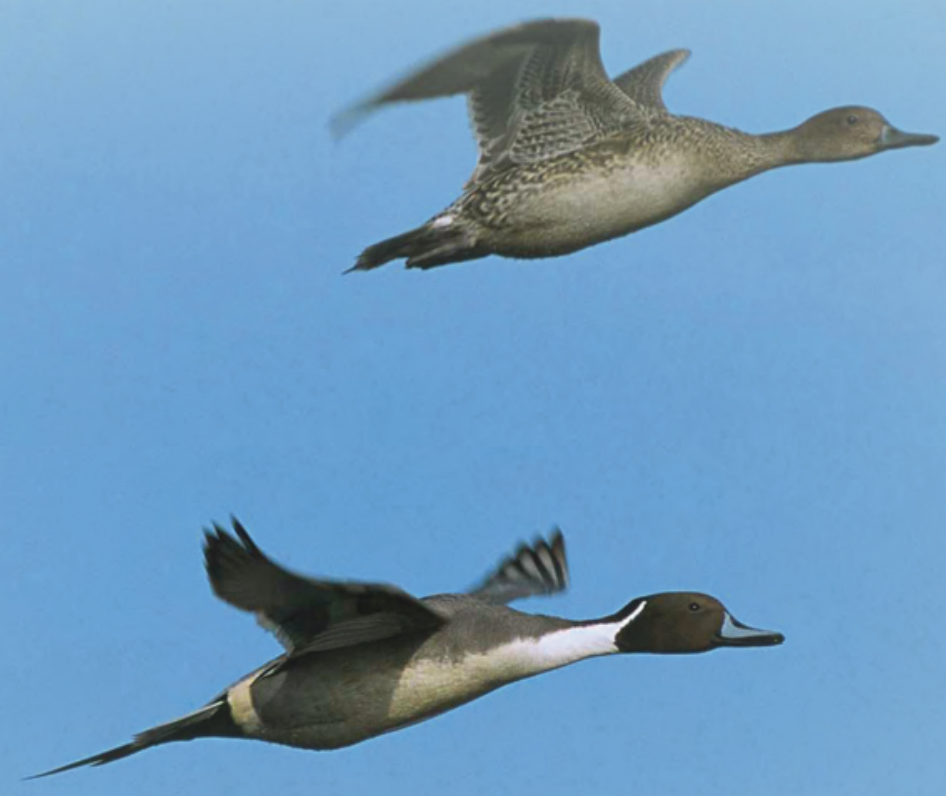

A pair of Northern Pintails, courtesy of public-domain-image.com. 


\title{
U.S. Geological Survey Science Strategy for Highly Pathogenic Avian Influenza in Wildlife and the Environment (2016-2020)
}

\author{
By M. Camille Harris, John M. Pearce, Diann J. Prosser, C. LeAnn White, A. Keith Miles, Jonathan M. \\ Sleeman, Christopher J. Brand*, James P. Cronin, Susan De La Cruz, Christine L. Densmore, Thomas W. \\ Doyle, Robert J. Dusek, Joseph P. Fleskes, Paul L. Flint, Gerald F. Guala, Jeffrey S. Hall, Laura E. Hubbard, \\ Randall J. Hunt, Hon S. Ip, Rachel A. Katz, Kevin W. Laurent, Mark P. Miller, Mark D. Munn, Andrew M. \\ Ramey, Kevin D. Richards, Robin E. Russell, Joel P. Stokdyk, John Y. Takekawa, and Daniel P. Walsh \\ [*authors listed from here forward are in alphabetical order]
}

\section{Executive Summary}

An outbreak of highly pathogenic avian influenza (HPAI) occurred in North American poultry and wildlife across 21 States (2014-2015). The Congressional Research Service estimated economy-wide losses of 3.3 billion dollars and the U.S. Department of Agriculture (USDA) has reported that over 50 million chickens and turkeys were dead or culled as a result of the HPAI outbreak. Because this disease is at the interface of wildlife, poultry, and humans, the complexity of resource management and policymaking decisions ranges from the local to national level. Avian influenza (AI) must be considered in an ecological context because its transmission and persistence is impacted by wildlife and environmental conditions. Predictive modeling of these viruses is challenging because of the diversity of avian host species, their migratory patterns, trophic interactions, and behavior. Climate, hydrological, and landscape changes, as well as mammalian bridge vectors and invasive species, have the potential to further enhance the complexity of AI dynamics in North America. The U.S. Geological Survey (USGS) has established longterm research on infectious diseases, birds, watersheds, and environmental conditions. USGS science has and will continue to significantly contribute to understanding, predictions, and decisions made by resource managers and policymakers about AI. This document provides a strategic direction for continued USGS HPAI research over the next five years (2016-2020) that builds upon that foundation. Implementation of novel objectives and proposed research actions with international, Federal, State, tribal, and academic partnerships will serve as the basis for developing robust decision-making frameworks to aid resource managers and policymakers faced with the new biological threat of HPAI. The strategy encompasses five longterm research science goals:
- Science Goal 1. Augment National HPAI Surveillance Plan. In 2015, the USDA led an interagency effort to revise a national surveillance plan for HPAI in wild migratory birds in the United States. This goal supplements that plan to ensure that research and surveillance efforts fill data gaps rather than collect redundant information.

- Science Goal 2. Determine mechanisms of HPAI disease spread in wildlife and the environment. The USGS has the unique capabilities to understand the spread and persistence of HPAI in wildlife, water, and sediments. As environmental conditions change, the USGS can predict and then work with resource managers to assess how these changes affect prevalence of AI viruses and population outcomes for wildlife, poultry, and public health.

- Science Goal 3. Characterize HPAI viruses circulating in wildlife. The USGS capabilities in genomics and bioinformatics allow for characterization of AI viruses circulating in wildlife and the environment. This information will contribute to spatiotemporal assessment of risk to poultry production, wildlife, and public health.

- Science Goal 4. Understand implications of avian ecology on HPAI spread. Migratory birds are the reservoirs of AI. The USGS is a leader in avian ecology research and has the capabilities to elucidate how intercontinental migration and avian community interaction influence HPAI spread.

- Science Goal 5. Develop HPAI forecasting and decision-making tools. The USGS has the expertise to provide formal HPAI decision consulting (for example, structured decision making) to management agencies. Based on management needs, the USGS will conduct 
decision analyses and develop risk and decision models. Scientific findings from the first four goals (and prior USGS research) can be integrated into risk assessment and decision models to improve AI detection and improve outbreak prevention strategies in poultry and wildlife management outcomes.

Identification of key decision points and critical information gaps (Science Goal 5) will guide prioritization of research in Science Goals 1-4 and serve as the basis for the development of models and data visualization tools. This science strategy will be reviewed annually to ensure that USGS HPAI research will address each goal area and refine scientific and decision-support products in order to provide timely information for key decisions being made by resource managers and policymakers.

\section{Vision}

Through the Science Strategy for HPAI in Wildlife and the Environment, the USGS will assess AI dynamics in an ecological context to inform decisions made by resource managers and policymakers from the local to national level. Through collection of unbiased scientific information on the ecology of AI viruses and wildlife hosts in a changing world, the USGS will enhance the development of AI forecasting tools and ensure this information is integrated with a quality decision process for managing HPAI.

\section{Introduction}

Historically, AI viruses that circulated in migratory birds were generally not highly pathogenic (capable of causing significant disease in poultry). Low pathogenic AI (LPAI) viruses that naturally circulate in aquatic birds (shorebirds, ducks, geese, and swans) rarely cause disease in poultry. However, influenza A viruses have genetic characteristics that promote constant change and unpredictable consequences. $\mathrm{AI}$ is a collection of viruses that are identified by two broad types of antigens: hemagglutinin (HA) and neuraminidase (NA). There are 144 possible combinations of subtypes (HA (H1-H16), NA (N1-N9)). AI viruses, primarily H5 and H7 subtypes, are classified as HPAI if they are capable of causing significant disease in poultry (Dugan and others, 2008). In the fall of 2014, HPAI was discovered in commercial poultry in southern British Columbia, Canada. In December 2014, strains of HPAI with genetic origins in East Asia were first detected in migratory birds in the United States (Ip and others, 2015). By the end of the 2014-2015 HPAI outbreak, over 50 million poultry across 15 States were dead or culled
(U.S. Department of Agriculture, 2016). Mortality also occurred in 9 wild bird species (primarily raptors), although in limited numbers. Detections of HPAI in wildlife provided poultry producers and public health officials with an early warning system for this disease. Understanding HPAI dynamics in wildlife can also provide insight into the spread of other influenza viruses. For example, the 2009 swine flu pandemic was a new strain of H1N1 that resulted from a triple reassortment of bird, swine, and human influenza viruses (Smith and others, 2009). The Obama Administration's National Security Strategy (https://www.whitehouse.gov/sites/default/ files/docs/2015_national_security_strategy.pdf) highlights the need to strengthen our capacity to counter biological threats. Specifically, the security strategy highlights the need for the U.S. to strengthen "our ability to prevent outbreaks and ensure sufficient capacity to respond rapidly and manage biological incidents." The U.S. will accelerate its work with international partners through the Global Health Security Agenda (GHSA) to pursue "a world that is safer and more secure from infectious diseases." As public health officials, poultry producers, and wildlife managers respond to HPAI viruses in the U.S., the USGS is uniquely positioned to provide scientific knowledge (from long-term and new research) on HPAI in wild birds and the environment, and provide decision support tools (see highlight 1: What is the Role of the USGS in the Federal Response to HPAI?). The USGS has extensive capabilities that include (1) characterizing molecular attributes of LPAI and HPAI viruses, (2) assessing the role of wildlife and the environment in disease spread and persistence, and (3) conducting traceconcentration monitoring of AI in the physical environment. The USGS is collaborating with the USDA to investigate the AI wildlife-poultry interface so that research results can promote the enhancement of biosecurity and improve domestic and wild avian population outcomes.

The overall goal of this USGS Science Strategy for HPAI in Wildlife and the Environment goes beyond just documenting the occurrence and distribution of AI viruses in wild birds. The USGS aims to understand the epidemiological processes and environmental factors that influence HPAI distribution and describe the mechanisms of transmission between wild birds and poultry. USGS scientists (Flint and others, 2015) developed a conceptual model describing the process linking HPAI dispersal in wild waterfowl to the outbreaks in poultry (fig. 1). This strategy focuses on five long-term science goals. These goals will help define and describe the processes outlined in the conceptual model with the ultimate goal of facilitating biosecurity and minimizing transfer of diseases across the wildlife-poultry interface. The first four science goals are focused on scientific discovery and the fifth goal is application-based (fig. 2). Decision analyses in the fifth goal will guide prioritization of proposed actions in the first four goals. 


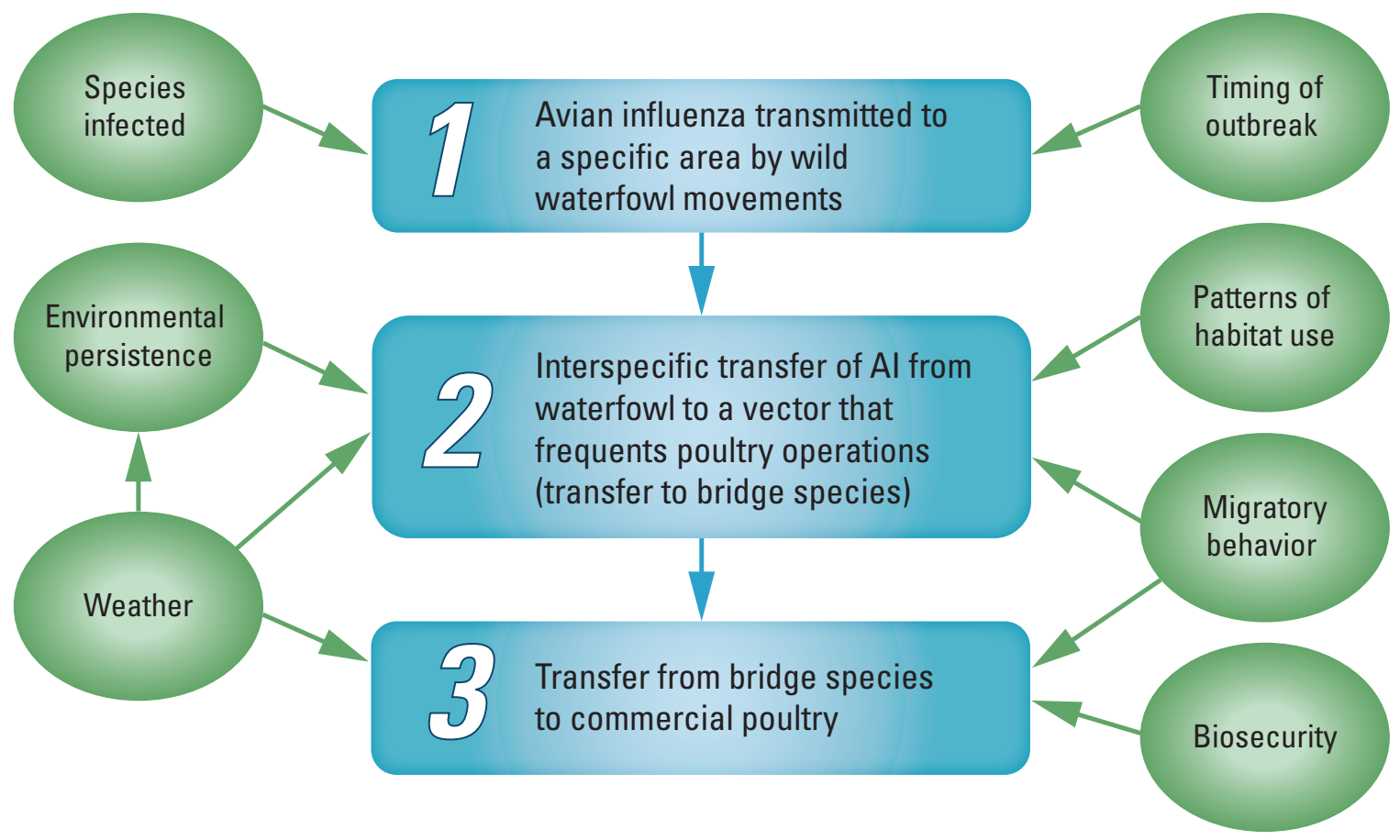

Figure 1. Conceptual model of the process of introduction and wild bird dispersal of $\mathrm{Al}$ and subsequent infection of commercial poultry holdings. The rectangular boxes (1-3) represent probabilities, and the circles represent external factors that influence the probabilities. It is unlikely that direct transfer between waterfowl and poultry occurs. It has been proposed that "bridge species" that interact or share habitats with wild waterfowl (and occur on poultry farms) facilitate the transfer. Potential bridge species may be birds, rodents, and (or) invertebrates. Figure modified from Flint and others (2015). Abbreviation: Al, avian influenza.

- Science Goal 1. Augment National HPAI Surveillance Plan. The U.S. Department of Agriculture (USDA) led an interagency effort to revise national surveillance and strategic plans for HPAI in wild migratory birds in the United States (U.S. Department of Agriculture 2015a,b). The USGS will support and supplement those plans to ensure that USGS research and surveillance efforts help to understand the distribution and occurrence of HPAI viruses at the continental scale. The USGS will focus on filling data gaps in the USDA plans rather than collect redundant information.

- Science Goal 2. Determine mechanisms of HPAI disease spread in wildlife and the environment. The USGS has the unique capabilities to understand the spread and persistence of HPAI in wildlife, water, and sediments. As environmental conditions change, the USGS can predict and then work with resource managers to assess how these changes affect prevalence of AI viruses and population outcomes for wildlife, poultry, and public health.

- Science Goal 3. Characterize HPAI viruses circulating in wildlife. The USGS capabilities in genomics and bioinformatics allow for characterization of AI viruses circulating in wildlife and the environment. The USGS will analyze the genetics of AI viruses detected in wildlife and the environment and assess the risk of introduction of novel strains. This information will be shared with our partners for poultry, susceptible wildlife, and public health AI risk assessments.

- Science Goal 4. Understand implications of avian ecology on HPAI spread. Migratory birds are the reservoirs of AI. The USGS is a leader in avian ecology research and has the capabilities to elucidate how intercontinental migration and avian community interaction influence HPAI spread. The USGS will work with the USDA to integrate avian movement and community ecology data with AI surveillance and poultry distribution data to develop poultry risk models.

- Science Goal 5. Develop HPAI forecasting and decision-making tools. The USGS has the expertise to provide formal HPAI decision consulting (for example, structured decision making) to management agencies. Based on the needs of resource managers, the USGS will conduct decision analyses and develop risk and decision models. Scientific findings from the first four goals (and prior USGS research) will be integrated into risk assessment and decision models to refine AI detection and outbreak prevention strategies for poultry and wildlife management. 


\section{Highlight 1: What is the Role of the USGS in the Federal Response to HPAI?}

The USGS is the science organization of the U.S. Department of the Interior, with a mission to provide reliable scientific information to describe and understand the Earth and minimize loss of life and property from natural disasters and hazards including wildlife disease. Since 2006, the USGS has been part of the Federal interagency team for the detection and response to HPAI viruses in North America. In particular, the USDA and the DOI actively coordinate with other State and Federal wildlife, agricultural, and human health agencies to understand AI distribution and dynamics with a goal of aiding natural resource managers, public health officials, and the poultry industry in making informed decisions. In December 2014, the USGS in collaboration with the USDA was instrumental in first detecting HPAI viruses in wild birds of North America.

The USGS conducts research on AI at multiple science centers across the nation and has amassed substantial internationally-recognized expertise investigating this disease. USGS scientists are (1) defining the role of migratory birds in viral spread, (2) characterizing genetics of viruses in wild birds, (3) determining environmental conditions affecting survival of the viruses in wetlands, (4) examining the potential role of non-waterfowl hosts, and (5) investigating the potential ecological consequences of infection in migratory birds. The USGS also has capabilities in AI diagnostics, surveillance, and mathematical modeling to map potential risk factors for disease spread between wild and domestic bird species. Additionally, USGS analytics expertise supports decision makers in management of diseases and natural resources.

The USGS has contributed substantial resources to enhance surveillance for HPAI across North America and to provide scientific information about the type, distribution, and wildlife species that harbor HPAI through timely public alerts; see Wildlife Health Bulletins at http://www.nwhc.usgs.gov/ publications/wildlife_health_bulletins/index.jsp, the online Wildlife Health Information Sharing Partnership event reporting system (WHISPers) at https://www.nwhc.usgs.gov/whispers/, and other USGS scientific publications.

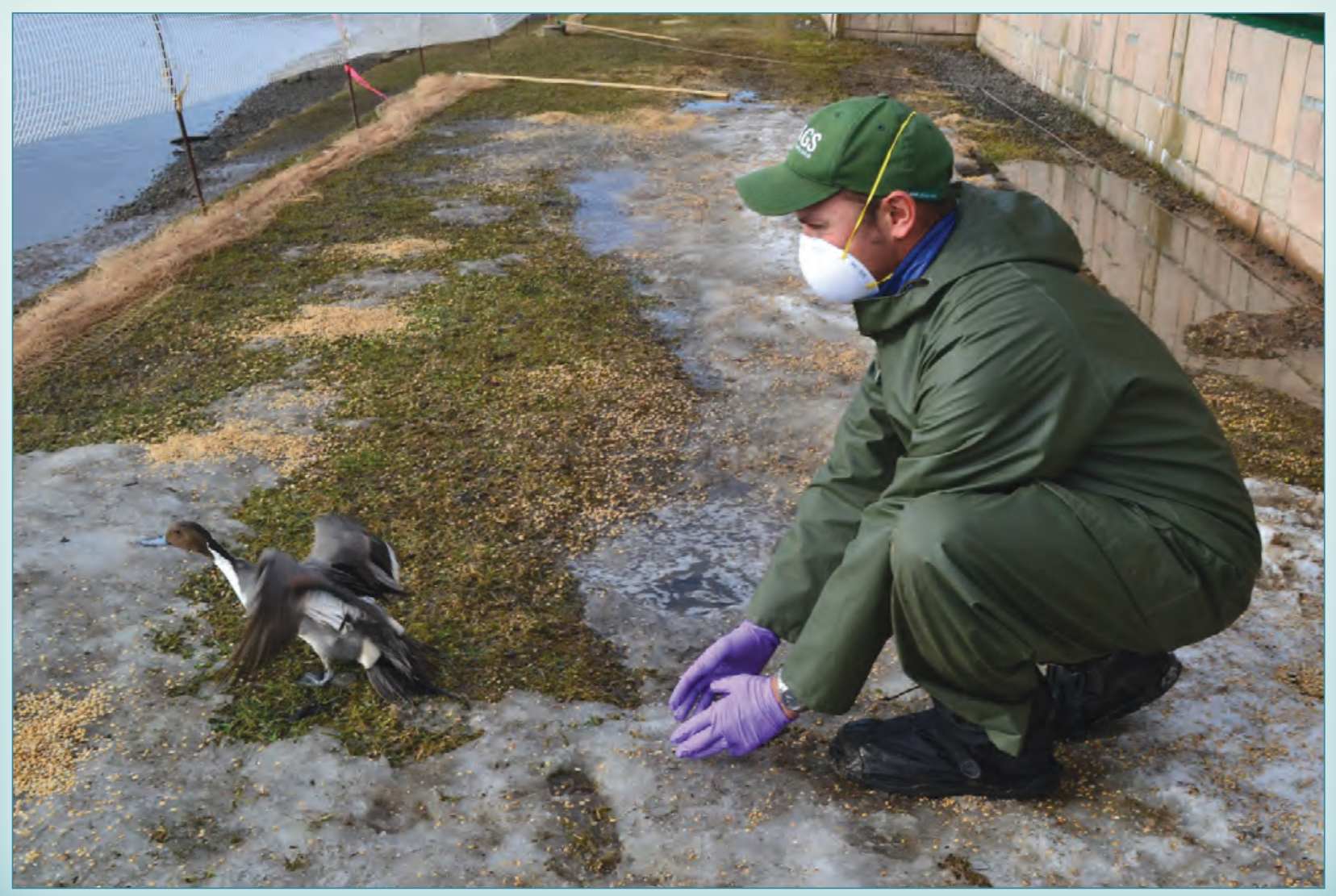

U.S. Geological Survey (USGS) geneticist Andy Ramey releases a Northern Pintail during research on avian influenza in Japan. USGS scientists are investigating the intercontinental movement of migratory birds and avian influenza (Dusek and others, 2014; Prosser and others, 2014; Ramey and others, 2014; Ramey and others, 2015). Photograph by the USGS. 


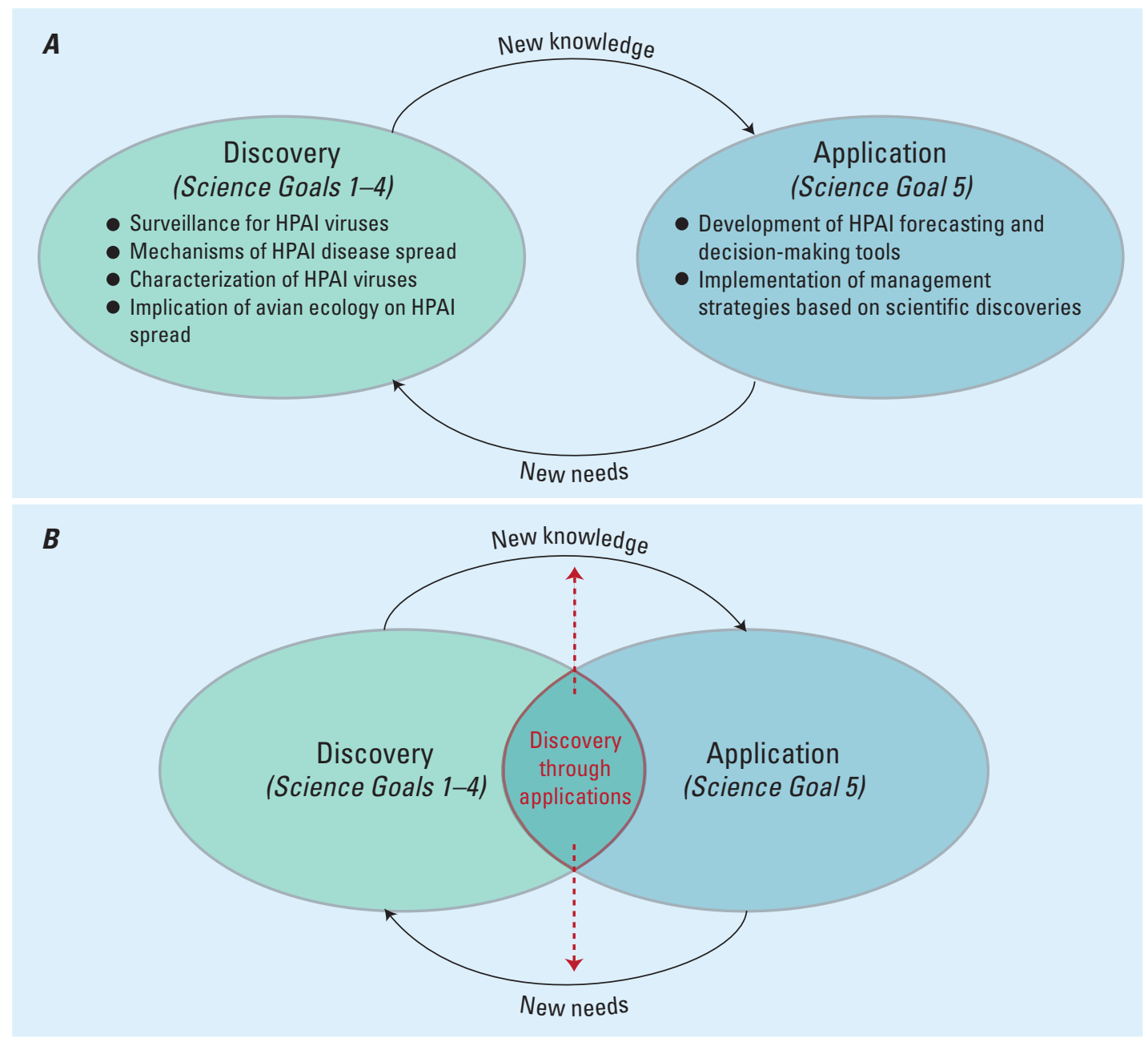

Figure 2. Diagram showing the U.S. Geological Survey (USGS) Science Strategy for HPAI in Wildlife and the Environment is based on the relationship between scientific discovery and the application of new knowledge. A, Discovery of new HPAl knowledge through surveillance and research (Science Goals 1-4) will lead to application of that knowledge (tool development and management strategies, Science Goal 5). Applications (Science Goal 5), in turn, will highlight new needs (Science Goals 1-4) that lead to additional discovery. $B$, The application of knowledge can spark discovery of new knowledge. Figure modified from Williams and others (2013). Abbreviation: HPAl, highly pathogenic avian influenza.

Identification of key decision points and critical information gaps (Science Goal 5) will guide prioritization of research in Science Goals 1-4 and serve as the basis for the development of models and data visualization tools. Each of the five science goals are elaborated in detail below and are further characterized into objectives and proposed actions (fig. 3). This strategy is congruent with the Department of the Interior (DOI) strategic plan for fiscal years 2014-2018 (see DOI's Goal \#3 of Mission Area 6: "Provide scientific data to protect, instruct, and inform communities" at https://www. doi.gov/sites/doi.gov/files/migrated/pmb/ppp/upload/DOIStrategic-Plan-for-FY-2014-2018-POSTED-ON-WEBSITE-4. pdf). Implementation of the 5 science goals will employ the strategic approaches outlined in the USGS Ecosystems Science Strategy (http://pubs.usgs.gov/circ/1383c/):

- Assess Information Needs for Ecosystem Science Through Enhanced Partnerships

- Promote the Use of Interdisciplinary Ecosystem Science

- Enhance Modeling and Forecasting

- Support Decision-Making 


\begin{tabular}{|c|c|c|c|c|}
\hline Science Goal 1 & Science Goal 2 & Science Goal 3 & Science Goal 4 & Science Goal 5 \\
\hline $\begin{array}{l}\text { Augment National HPAI } \\
\text { Surveillance Plan }\end{array}$ & $\begin{array}{l}\text { Determine mechanisms } \\
\text { of HPAI disease } \\
\text { spread in wildlife and } \\
\text { the environment }\end{array}$ & $\begin{array}{l}\text { Characterize HPAI } \\
\text { viruses circulating in } \\
\text { wildlife }\end{array}$ & $\begin{array}{l}\text { Understand implications } \\
\text { of avian ecology on } \\
\text { HPAI spread }\end{array}$ & $\begin{array}{l}\text { Develop HPAI forecast- } \\
\text { ing and decision-mak- } \\
\text { ing tools }\end{array}$ \\
\hline $\begin{array}{l}\text { Objective 1: } \\
\text { Develop tools and strate- } \\
\text { gies for early HPAI } \\
\text { detection in wildlife } \\
\text { and the environment }\end{array}$ & $\begin{array}{l}\text { Objective 1: } \\
\text { Determine mechanisms } \\
\text { of HPAI spread and } \\
\text { persistence in wildlife }\end{array}$ & $\begin{array}{c}\text { Objective 1: } \\
\text { Characterize AI viruses } \\
\text { circulating in wild birds }\end{array}$ & $\begin{array}{c}\text { Objective 1: } \\
\text { Map spatial and temporal } \\
\text { distributions of wild } \\
\text { and domestic avian } \\
\text { populations for risk } \\
\text { model development }\end{array}$ & $\begin{array}{l}\text { Objective 1: } \\
\text { Provide decision support } \\
\text { to management agen- } \\
\text { cies }\end{array}$ \\
\hline $\begin{array}{l}\text { Proposed Action 1: } \\
\text { Develop new detection } \\
\text { strategies for HPAI in } \\
\text { environmental samples }\end{array}$ & $\begin{array}{l}\text { *Proposed Action 1: } \\
\text { Experimental studies } \\
\text { to understand the role } \\
\text { of sea ducks in HPAI } \\
\text { movement, transmis- } \\
\text { sion, and evolution }\end{array}$ & $\begin{array}{l}\text { *Proposed Action 1: } \\
\text { Characterize HPAI } \\
\text { viruses in wild birds } \\
\text { across North America }\end{array}$ & $\begin{array}{l}\text { Proposed Action 1: } \\
\text { Develop wild and } \\
\text { peridomestic bird } \\
\text { distribution models as } \\
\text { inputs for disease risk } \\
\text { assessments }\end{array}$ & $\begin{array}{l}\text { Proposed Action 1: } \\
\text { Work with management } \\
\text { agencies to develop a } \\
\text { quality HPAI decision- } \\
\text { making framework }\end{array}$ \\
\hline $\begin{array}{l}\quad \text { Objective 2: } \\
\text { Conduct HPAI surveil- } \\
\text { lance in wild birds and } \\
\text { peridomestic wildlife }\end{array}$ & $\begin{array}{l}\text { Objective 2: } \\
\text { Determine mechanisms } \\
\text { of HPAI spread and } \\
\text { persistence in the envi- } \\
\text { ronment }\end{array}$ & $\begin{array}{l}\text { Proposed Action 3: } \\
\text { Characterize LPAI and } \\
\text { HPAI strains in perido- } \\
\text { mestic wild birds near } \\
\text { poultry operations }\end{array}$ & $\begin{array}{l}\text { Proposed Action 3: } \\
\text { Examine the influence } \\
\text { of climate change on } \\
\text { bird migration and its } \\
\text { implications on AI } \\
\text { dynamics }\end{array}$ & $\begin{array}{l}\text { Proposed Action 3: } \\
\quad \text { Refine HPAI research } \\
\text { priorities based on } \\
\text { management partner } \\
\text { needs }\end{array}$ \\
\hline $\begin{array}{l}\text { *Proposed Action 2: } \\
\text { Collaborate with } \\
\text { USDA to conduct } \\
\text { HPAI surveillance of } \\
\text { potential hosts near } \\
\text { poultry facilities }\end{array}$ & $\begin{array}{l}\text { Proposed Action 2: } \\
\text { Examine persistence of } \\
\text { AI viruses in sediment }\end{array}$ & $\begin{array}{l}\text { Proposed Action 1: } \\
\text { Characterize AI viruses } \\
\text { circulating in perido- } \\
\text { mestic mammals near } \\
\text { poultry operations }\end{array}$ & $\begin{array}{l}\text { Proposed Action 1: } \\
\text { Develop quantitative } \\
\text { flyway maps of AI } \\
\text { reservoir species }\end{array}$ & $\begin{array}{l}\text { Proposed Action 1: } \\
\text { Develop dynamic } \\
\text { occupancy models to } \\
\text { estimate probabilities } \\
\text { of AI occurrence }\end{array}$ \\
\hline $\begin{array}{l}\text { Proposed Action 3: } \\
\text { Conduct meta-analysis } \\
\text { of HPAI surveillance } \\
\text { strategies }\end{array}$ & $\begin{array}{l}\text { *Proposed Action 3: } \\
\text { Characterize AI trans- } \\
\text { port in groundwater }\end{array}$ & $\begin{array}{l}\text { Proposed Action 2: } \\
\text { Characterize AI viruses } \\
\text { circulating in feral } \\
\text { swine }\end{array}$ & $\begin{array}{l}\text { Proposed Action 2: } \\
\text { Determine popula- } \\
\text { tion connectivity of } \\
\text { avian AI reservoir } \\
\text { species through genetic } \\
\text { analyses }\end{array}$ & $\begin{array}{l}\text { Proposed Action 2: } \\
\text { Conduct a meta- } \\
\text { analysis of existing AI } \\
\text { mechanistic models }\end{array}$ \\
\hline
\end{tabular}

Figure 3. Illustration showing the U.S. Geological Survey (USGS) Science Strategy for HPAI in Wildlife and the Environment (2016-2020) is focused on five long-term science goals. Science goals are characterized into objectives (light blue) and proposed actions (tan). Ongoing proposed actions are shown with an asterisk $\left.{ }^{*}\right)$. Abbreviations: Al, avian influenza; DOI, Department of the Interior; HPAl, highly pathogenic avian influenza; LPAl, low pathogenic avian influenza; USDA, U.S. Department of Agriculture. 


\begin{tabular}{|c|c|}
\hline Science Goal 1 & \multicolumn{1}{|c|}{ Science Goal 2} \\
\hline $\begin{array}{c}\text { Augment National HPAI } \\
\text { Surveillance Plan }\end{array}$ & $\begin{array}{c}\text { Determine mechanisms } \\
\text { of HPAI disease } \\
\text { spread in wildlife and } \\
\text { the environment }\end{array}$ \\
\hline
\end{tabular}

Proposed Action 4:

Investigate climate variability and change as a driver of AI persistence and spread

\section{Objective 3:}

Determine mechanisms of HPAI spread and persistence in peridomestic wildlife found near poultry operations

\section{Proposed Action 1:} Interagency workshop on the wildlifedomestic animal HPAI interface

* Proposed Action 2: Field research to examine the role of wild birds in HPAI movement

* Proposed Action 3 : Experimental studies to understand the role of wild birds in HPAI movement, transmission, and evolution

* Proposed Action 4: Conduct research to examine the role of non-avian species in HPAI movement and transmission

Objective 4:

Determine implications of LPAI and HPAI exposure for wildlife

Proposed Action 1: Investigate population level impacts of HPAI exposure on DOI trust species

Proposed Action 2:

Determine the genetic factors associated with HPAI resistance and susceptibility

Proposed Action 3: Compare wildlife HPAI immune responses for targeted HPAI surveillance and management

\begin{tabular}{|c|c|}
\hline \multicolumn{1}{|c|}{ Science Goal 3} & \multicolumn{1}{c|}{ Science Goal 4} \\
\hline $\begin{array}{c}\text { Characterize HPAI } \\
\text { viruses circulating in } \\
\text { wildlife }\end{array}$ & $\begin{array}{c}\text { Understand implications } \\
\text { of avian ecology on } \\
\text { HPAI spread }\end{array}$ \\
\hline
\end{tabular}

Objective 3:
Characterize HPAI
viruses circulating
outside North America
and on the continental
fringes with potential
of intruduction

Proposed Action 3: Characterize landscape connectivity between avian AI reservoirs and wild birds susceptible to HPAI disease

\section{*Proposed Action 1:} Characterize AI viruses circulating in wildlife outside of North America

\section{* Proposed Action 2:} Characterize AI viruses on continental fringes of North America

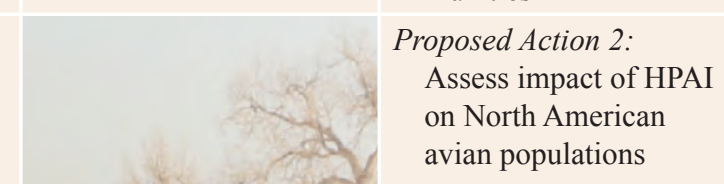

\section{Objective 3:}

Investigate HPAI

transmission in avian communities and the impact of HPAI on avian populations

Proposed Action 1:

Determine HPAI transmission pathways within ecological communities

Proposed Action 2 : on North American avian populations

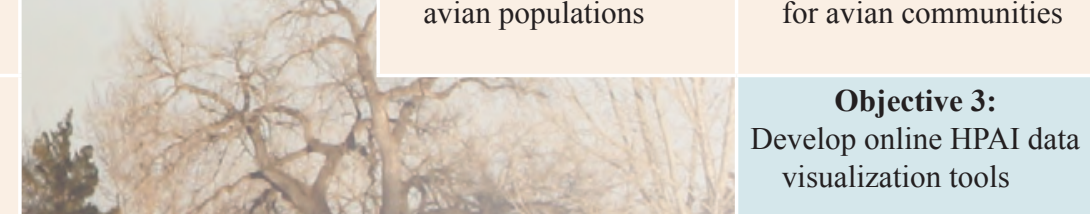
visualization tools

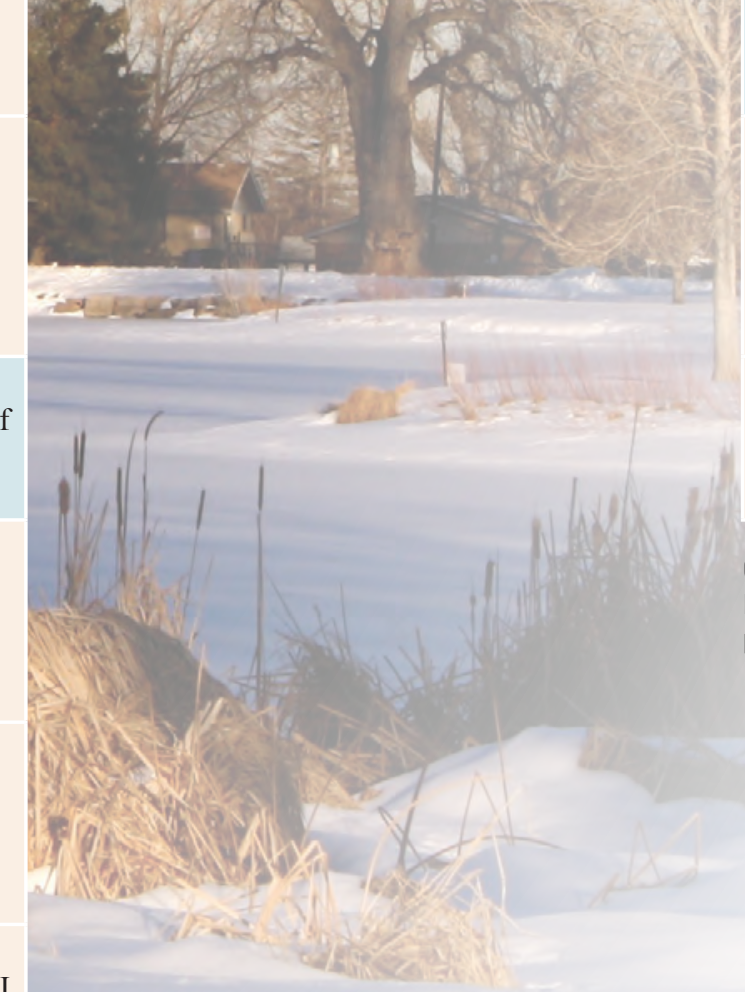

Figure 3. Illustration showing the U.S. Geological Survey (USGS) Science Strategy for HPAI in Wildlife and the Environment (20162020 ) is focused on five long-term science goals. - Continued. 
Science Outcomes of the

\section{U.S. Geological Survey Science Strategy on HPAI in Wildlife and the Environment}

The U.S. now has to contend with potentially endemic HPAI viruses in poultry and wildlife. HPAI has negatively impacted the poultry industry and may impact populations of susceptible wildlife species and public health. Because migratory birds and environmental factors are important in the spread and persistence of AI viruses, the USGS is wellpositioned to support decision-makers through the development of surveillance, risk assessment, and forecasting tools (see appendix 2). In collaboration with international, Federal, State, tribal, and non-governmental collaborators, the USGS will accomplish the following outcomes in accordance with the five science goals of the Science Strategy on HPAI (fig. 3):

\section{Science Goal 1: Augment National HPAI Surveillance Plan.}

- New, validated sampling and diagnostic HPAI strategies.

- New and strengthened international partnerships for early HPAI detection.

- Completed meta-analysis of HPAI surveillance strategies.

Science Goal 2: Determine mechanisms of HPAI disease spread in wildlife and the environment.

- Description of mechanisms of HPAI maintenance and spread (transmission and movement to new areas) in avian and non-avian wildlife and the environment.

Science Goal 3: Characterize HPAI viruses circulating in wildlife.

- Genetic characterization of viruses circulating in avian and non-avian wildlife.

Science Goal 4: Understand implications of avian ecology on HPAI spread.

- Description of distribution, migratory connectivity, and aspects of avian ecology that may influence HPAI persistence and spread.

Science Goal 5: Develop HPAI forecasting and decision making tools.

- Guidance for the development of disease management strategies and identification of key uncertainties that need to be addressed through future research.

- HPAI risk assessment and predictive modeling tools to identify high risk areas and populations for HPAI transmission.
- Rapid response decision model that forecasts how to get in front of potential and unknown future outbreaks. The output from the model will be designed to facilitate "proactive prevention."

- Online data visualization tools for situational awareness, education, and access to developed predictive and decision models.

\section{U.S. Geological Survey HPAI Science Goals}

\section{Science Goal 1: Augment National HPAI Surveillance Plan}

One Health is the recognition that public health and domestic animal health is linked to wildlife health and the environment (Zinsstag and others, 2011). Approximately 60 percent of emerging human infectious diseases are zoonotic. Over 70 percent of these zoonoses originate in wildlife (Jones and others, 2008). Many of these diseases also affect domestic animals, resulting in economic consequences. Through sustained research and response to changes in wild populations and the environment, these pathogens of concern may be detected before they reach agricultural or human populations. Indeed it was through continued passive monitoring of wild birds for avian disease mortality events that HPAI was first detected in the U.S. by the USDA and USGS in December 2014. The HPAI intercontinental group A (icA) H5 viruses have since been detected in wild birds (waterfowl, birds of prey, and a songbird), captive wild birds (birds of prey) and domestic fowl (backyard flocks and commercial poultry operations) in the United States (U.S. Department of Agriculture 2015c). HPAI outbreaks in U.S. commercial poultry operations (primarily laying hens and turkeys) have resulted in an estimated 3 billion dollar economic impact to the United States (Greene, 2015).

National scale surveillance for HPAI was outlined in a Surveillance Plan for HPAI in Waterfowl in the U.S. (U.S. Department of Agriculture, 2015a) developed by the USDA, USGS, U.S. Fish and Wildlife Service (USFWS), and the National Flyway Council. Samples collected through this Surveillance Plan will provide information on the distribution of HPAI in the U.S. through the sampling of dabbling ducks in priority U.S. watersheds. The USGS is collaborating with the USDA to augment its current contributions to this multiagency plan by developing advanced tools for environmental and wildlife HPAI surveillance, conducting HPAI wildlife surveillance (see highlight 2: The Importance of Long-Term Research for Disease Surveillance), and analyzing surveillance strategies to ensure sampling designs are efficient. 


\section{Zighlight 2: The Importance of Long-Term Research for Disease Surveillance}

Informed surveillance and research plans rely upon scientific baselines established through prior work and expert knowledge. The USGS long-term research on wildlife, hazards, hydrology, and data modeling and visualization provide an essential foundation for current and future disease surveillance strategies (see appendix 2). These long-term research platforms provide a base of knowledge to compare with novel and emerging conditions and to promote national preparedness. Some examples of long-term USGS science that will inform current and future HPAI surveillance strategies include the National Wildlife Health Center mortality and morbidity investigations, decision science, and quantitative ecology research (see appendix 2), as well as ongoing research examining the intercontinental dispersal and introduction of influenza A viruses into the United States (for example, Koehler and others, 2008; Reeves and others, 2013; Dusek and others, 2014; Ramey, Walther, and others, 2014; Ramey, Reeves, Sonsthagen, and others, 2015).

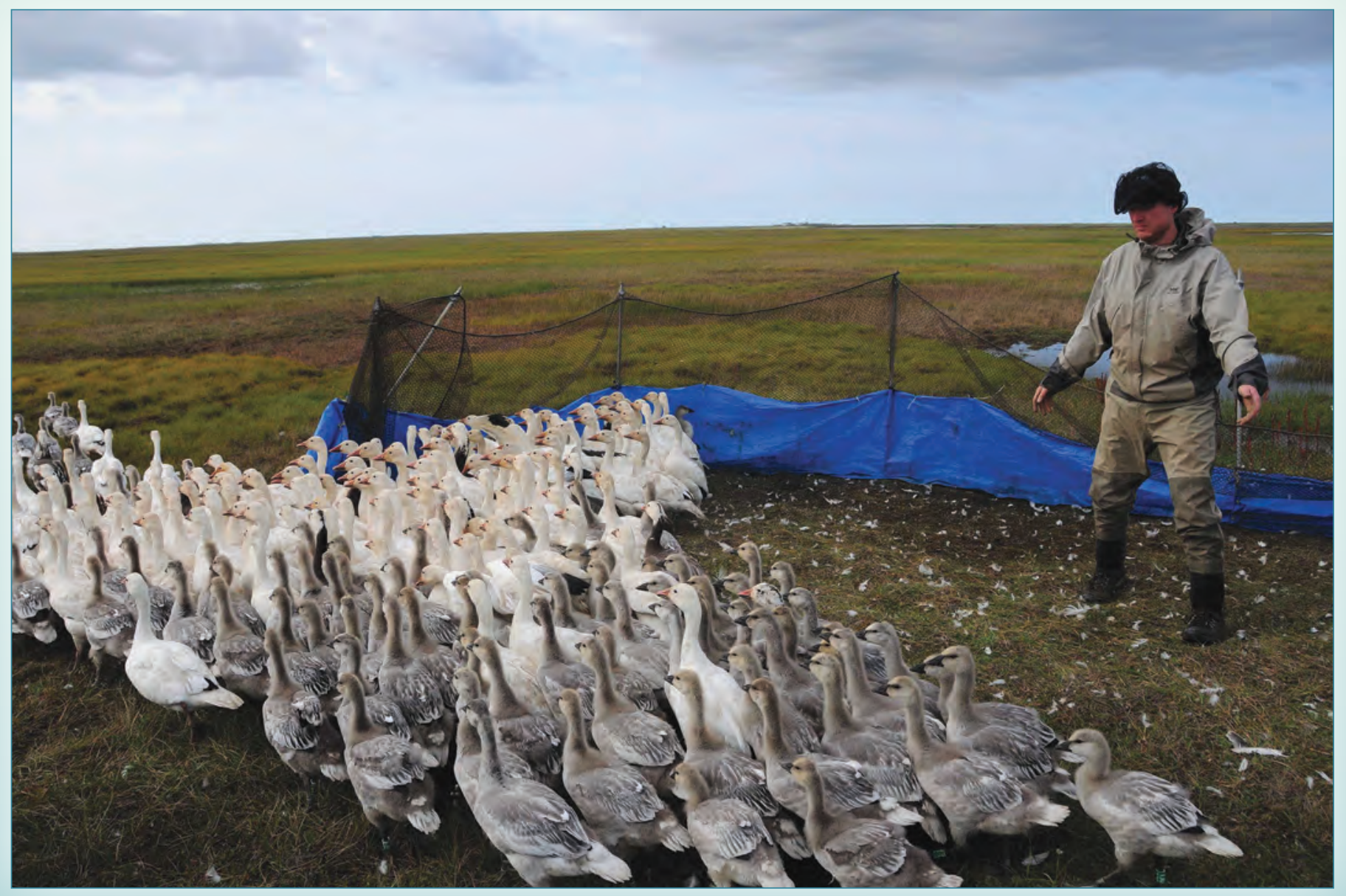

Alaska Department of Fish and Game biologist Jason Schamber releases Lesser Snow Geese from a capture pen in northern Alaska. U.S. Geological Survey (USGS) scientists are investigating the dynamics of avian influenza in lesser snow geese (Reeves and others, 2013; Samuel and others, 2015). Photograph by the USGS. 


\section{Objective 1. Develop tools and strategies for early HPAI detection in wildlife and the environment.}

Surface water contaminated by infected waterfowl is considered a primary source for the transmission of AI in wild bird populations. The persistence of AI viruses in the environment (for example, in water and sediment) may influence the transmission and distribution of HPAI. Distribution is also influenced by the movement of AI viruses by wild birds across continents.

\section{Proposed Action 1. Develop new detection strategies for HPAl in environmental samples.}

In collaboration with the USDA, the USGS will refine and validate methods to detect low concentrations of HPAI viruses in environmental samples and determine molecular subtype associations in samples. Portable, rapid molecular detection kits are being validated by the USGS for invasive species detection (Merkes and others, 2016). This technology has been used to shorten the field diagnostic time for Ebola viruses (Kurosaki and others, 2016) and has the potential to provide new avenues for increased sensitivity and decreased time to HPAI detection. Based on partner needs, the USGS novel environmental detection strategies can support international and national HPAI surveillance. Rapid detection is essential for applying effective management actions (Flint and others, 2015).

\section{Proposed Action 2. Detect potential HPAl introductions into the United States}

Through an international network, the USGS has found genetic evidence of intercontinental transport of AI viruses by wild birds (Koehler and others, 2008; Dusek and others, 2014; Lee and others, 2015; Ramey, Reeves, Sonsthagen, and others, 2015). The USGS will develop an international sampling network to detect and monitor possible areas of HPAI introductions into the U.S. This network will build on the Global Health Security Agenda (GHSA), an effort in which the United States has committed to support 30 developing countries in their capabilities to prevent, detect, and respond to infectious disease outbreaks (https://www.whitehouse.gov/ the-press-office/2015/11/16/fact-sheet-us-commitment-globalhealth-security-agenda). This surveillance network could also promote an early warning system for HPAI viruses that could enter the United States.

\section{Objective 2. Conduct HPAI surveillance in wild birds and peridomestic wildlife.}

The Interagency Wild Bird HPAI Surveillance Plan developed by the USDA, the USGS, and other agencies focuses on dabbling ducks in watersheds that have been prioritized based on AI risk (U.S. Department of Agriculture, 2015a). To better elucidate HPAI dynamics in North America, the USGS will also conduct surveillance of potential alternative hosts (peridomestic wildlife). Field surveillance integrated into long-term avian ecology research will also support the interagency plan. Integrated conclusions from these efforts about the distribution of AI viruses will be used to develop predictive models that will be communicated to resource managers.

Proposed Action 1. Implement the National Interagency Surveillance Plan for HPAl in waterfowl.

The USGS will assist in implementation of the National Surveillance Plan for HPAI (U.S. Department of Agriculture, 2015a). The USGS National Wildlife Health Center, part of the USDA's National Animal Health Laboratory Network, will continue to conduct diagnostic HPAI testing of samples from live wild birds, from hunter-harvested waterfowl, and from dead wild birds as part of morbidity/mortality event investigations. Moreover, USGS long-term wild bird surveillance efforts will include sampling outside of the priority watersheds.

Proposed Action 2. Collaborate with the USDA to conduct HPAI surveillance of potential alternative hosts in the immediate vicinity of infected poultry facilities.

The USDA has speculated that rodents and small wild birds are involved in the movement of HPAI within the United States (U.S. Department of Agriculture, 2015d). The USGS will continue a 2015 pilot study of influenza surveillance in peridomestic wildlife (such as rodents, raccoons, and songbirds) and will work with the USDA-APHIS ${ }^{1}$ National Feral Swine Damage Management Program to examine feral swine and other invasive species. These data will support interagency HPAI surveillance efforts and provide data for decision-support tools.

${ }^{1}$ Animal and Plant Health Inspection Service

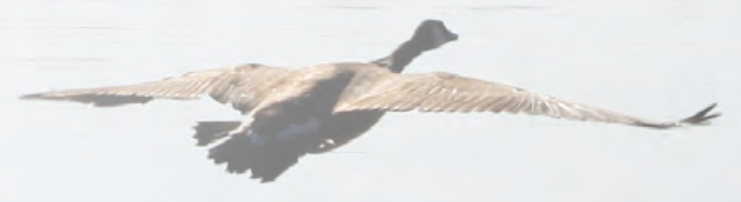


Proposed Action 3. Conduct meta-analysis of HPAl surveillance strategies.

Meta-analyses of HPAI surveillance sample strategies (such as temporal, geographic, species, and sample type) will be conducted to assess the importance of various factors in surveillance design. Through interagency collaboration and an adaptive management approach, surveillance strategies for HPAI will be refined to improve efficiency based on these results.

\section{Science Goal 2: Determine Mechanisms of HPAI Disease Spread in Wildlife and the Environment}

Since the initial detection of icA H5 HPAI in the U.S., the spread of highly pathogenic viruses across the Pacific, Central, and Mississippi Flyways has been unpredictable. Phylogenetic analyses by the USDA and the USGS suggest that migratory birds introduced HPAI H5N8 to the U.S. from Eurasia (Lee and others, 2015). However, it is unclear if the spread of icA $\mathrm{H} 5$ viruses across poultry facilities is consistent with wild bird movements or if viruses are spread in other ways. The USDA has speculated about rodents, passerine birds, and environmental factors in the dissemination of HPAI within the United States (U.S. Department of Agriculture, 2015d). In order to forecast future HPAI outbreaks, we need to better understand the mechanisms of spread and persistence in wildlife and the environment (see highlight 3: AI in the Environment).

\section{Objective 1. Determine mechanisms of HPAI spread and persistence in wildlife.}

While dabbling ducks are known reservoirs of AI (Keawcharoen and others, 2008), the role of other wild bird species and non-avian wildlife in HPAI spread and persistence has not been fully elucidated. Research suggests that filter-feeding organisms may play a role in AI dynamics (Huyvaert and others, 2012; Meixell and others, 2013). The USGS continues to assess the significance of non-avian wildlife in HPAI spread and persistence. Additionally, the USGS has established captive wild bird research colonies and long-term avian ecology studies, which can serve as important resources for future AI research in wild birds.

\section{Proposed Action 1. Conduct experimental HPAI studies} to understand the role of sea ducks in the movement, transmission, and evolution of these viruses.

Additional information is needed on sea duck responses to HPAI viruses. These species are long distance migrants that breed in far northern regions of the globe and congregate in wintering areas along coasts. The few studies available suggest they are often exposed to AI viruses, but it is unclear where and when active infection and shedding take place (Hall and others, 2015; Ramey, Reeves, Poulson, and others, 2015). Using established sea duck colonies, the USGS has begun collaborating with the USDA to evaluate the pathogenesis, minimum infectious dose, asymptomatic period, routes of shedding, and transmissibility of HPAI in sea duck species. This information will be integrated into risk models (Science Goal 5, Objective 2).

\section{Proposed Action 2. Examine the role of filter-feeding} organisms in HPAI persistence, transmission, or inactivation.

Experimental research has shown that AI viruses can bioaccumulate in filter-feeding organisms like common water fleas (Meixell and others, 2013), clams (Huyvaert and others, 2012) and zebra mussels (Stumpf and others, 2010). USGS field surveillance has also detected AI in a sentinel oyster (Densmore and others, 2016). Because bivalves are an important prey species for diving ducks (Richman and Lovvorn, 2004), it is also important to investigate the possibility of AI transmission from invertebrate prey to water bird species.

\section{Objective 2. Determine mechanisms of HPAI spread and persistence in the environment.}

Aquatic birds (waterfowl and shorebirds) are the primary biotic reservoirs of LPAI viruses, often showing no signs of illness. Viruses replicate in the intestinal tract, leading to high concentrations being shed with excrement into the environment (Webster and others, 1978). LPAI viruses can persist in surface waters under certain environmental conditions. Experimentally, Eurasian H5N1 viruses are similar to LPAI in regards to survivability in water (Brown and others, 2014). Additional field and laboratory research is needed to examine HPAI spread and persistence in the environment (surface water, groundwater, and sediment). Geospatial data from this environmental surveillance can be used for novel Landsatbased identification of similar HPAI high-risk habitats for the development of HPAI forecasting and risk assessment tools (Science Goal 5, Objective 2).

Proposed Action 1. Determine hydrologic characteristics and flows that facilitate persistence of HPAl in fresh and brackish waters.

The National Surveillance Plan for HPAI (U.S. Department of Agriculture, 2015a) identifies high priority watersheds for surveillance based on historic hot spots of LPAI virus detections and known congregation of dabbling ducks. In order to understand how HPAI is spread in a watershed, it is crucial to examine its persistence in water (groundwater and surface water). Experimental work has shown that low temperatures, a neutral-basic $\mathrm{pH}$, and low salt and ammonia concentrations are associated with LPAI persistence (Keeler and others, 2014). Under certain conditions, HPAI infectivity has been documented in brackish water (Domanska-Blicharz and 
others, 2010). While hydrologic transport has been considered in models of water-borne parasites (Gurarie and Seto, 2009), this aquatic connectivity has not been examined for $\mathrm{AI}$ in watersheds. Through field and laboratory research, the USGS will determine the water conditions and flows that allow HPAI to remain infectious and persist in watersheds. These data will be integrated into risk assessment models (Science Goal 5, Objective 2).

\section{Proposed Action 2. Examine persistence of Al viruses in sediment.}

Low pathogenic avian influenza viruses have been detected in pond sediments suggesting sediment may be important for the maintenance of AI viruses (Lang and others, 2008). It is unknown how long HPAI remains infectious in similar settings and what factors allow for viral persistence. While the fate and transport of water-borne parasites in sediment has been considered (Ferguson and others, 2003), the particle size with which AI viruses are transported and its sedimentation in watersheds has not been fully examined. Field and experimental research will be conducted to understand the transport and persistence of HPAI in sediment.

\section{Proposed Action 3. Characterizing Al transport to and from groundwater.}

In addition to ponds, waste water lagoons are known surface water features that birds frequent. Further examining AI occurrence in waste water lagoons could lead to identification of another transport mechanism as lagoons are frequently emptied and spray irrigated on croplands. A USDA and USGS proof-of-concept study provided the first known documentation of influenza A (H5) RNA in groundwater underlying a poultry operation that was infected with HPAI during the spring 2015 outbreak (Hubbard and others, 2016). Previous research has documented that groundwater concentrations of human enteric viruses are highly transient and variable because of virus inactivation, dilution by well pumping, changes in source strength, and changes in virus transport driven by factors such as precipitation (Borchardt and others, 2012; Bradbury and others, 2013). The USGS will continue this collaborative research with the USDA, expanding the geographic coverage of infected poultry facilities and creating a spatiotemporal dataset of groundwater and poultry waste water lagoon samples for HPAI. This groundwater data will be integrated into HPAI risk assessment and predictive models (Science Goal 5, Objective 2).

\section{Proposed Action 4. Investigate climate variability and change as a driver of Al persistence and spread.}

Variability in patterns of air and water temperatures and precipitation is known to impact the dynamics of waterborne diseases (Rose and others, 2001; Bradbury and others 2013; Morand and others, 2013). Yet the influence of climate variability on AI transport, spread, and persistence in North American watersheds is unknown. The USGS will evaluate AI virus detections (Science Goal 2, Objective 2, Proposed Actions 1-3) in light of present and past climatic conditions to determine if climate variability influences AI dynamics. The results will be communicated to resource managers and incorporated into HPAI risk assessment and predictive models (Science Goal 5, Objective 2).

\section{Objective 3. Determine mechanisms of HPAI spread and persistence in peridomestic wildlife found near poultry operations.}

Research is needed to understand the role of peridomestic wild birds (such as resident Canada geese, European starlings, sparrows, and doves) and non-avian wildlife (such as small mammals) in HPAI spread (Hall and others, 2008; Tejeda and others, 2015). In 2015, HPAI was detected in resident Canada geese in Michigan and a songbird (black-capped chickadee) in Minnesota (U.S. Department of Agriculture, 2015c). Similar to birds of prey (Hall and others, 2009), these species displayed signs of neurological disease and died. It has been suggested that peridomestic wild birds may serve as bridge species for HPAI spread onto poultry operations (Flint and others, 2015), and there is experimental evidence that songbirds can spread HPAI to poultry through shared water (Jones and others, 2015). Likewise, experimental evidence suggests a role for small mammals in the movement and transmission of HPAI (Hall and others, 2008; Tejeda and others, 2015). USGS scientists will enhance partnerships with USDA scientists to determine the role of peridomestic wildlife in HPAI spread and persistence.

Proposed Action 1. Conduct an interagency workshop on wildlife-domestic animal HPAI interface.

An interagency (USGS, USDA) workshop will be conducted to bring together scientists for the coordination of studies that examine the HPAI interface between wildlife and domestic animals. Complementary capabilities from the participating agencies will be leveraged to ensure future interagency studies will meet the needs of decision-makers and managers coordinating AI control efforts.

\section{Proposed Action 2. Conduct field research to examine the role of peridomestic wild birds in the movement and transmission of HPAl.}

The USGS will collaborate with the USDA to conduct AI research on peridomestic wild birds in the vicinity of poultry facilities in regions where HPAI is detected. The resulting information will be used to refine models through reductions in uncertainty and identification of alternative biosecurity actions to dampen the economic impact of HPAI on poultry operations. 


\section{Flighlight 3: Al in the Environment}

Environmental features (water and soil) have been identified as playing potentially important roles in the maintenance of AI viruses. Additionally, multi-year assessments of AI viral communities suggest that genetic diversity is likely maintained in the environment as well as in wildlife. Changes in aquatic ecosystems related to climate warming or other environmental stressors could have impacts on the dynamics of the host-pathogen-environment relationship. Therefore, an understanding of the factors allowing persistence and transmission of pathogens from water and soil is needed to determine their significance to wildlife, domestic animals, and humans. The USGS demonstrated that water and filter feeding organisms can play a role in the maintenance of AI viruses and has tested methods for detecting and determining the survival of viruses in the environment (Dalton and others,
2009; Millen and others, 2012; Francy and others, 2013; Meixell and others, 2013; see appendix 2). The Laboratory for Infectious Disease in the Environment (LIDE), a joint facility of the USGS and USDA Agricultural Research Service, has been able to detect very low levels of AI virus in groundwater and surface-water samples. The LIDE collected and analyzed samples from groundwater and surface water related to the 2015 HPAI outbreak, and scientists from the LIDE are trained in USDA highly pathogenic AI responder methods. The LIDE uses molecular and culture techniques to quantify AI viruses in environmental samples and determine the infectivity of AI viruses. LIDE scientists identified recent $\mathrm{AI}$ gene sequence mutations associated with the 2015 outbreak that allowed them to more reliably detect and identify the AI virus.

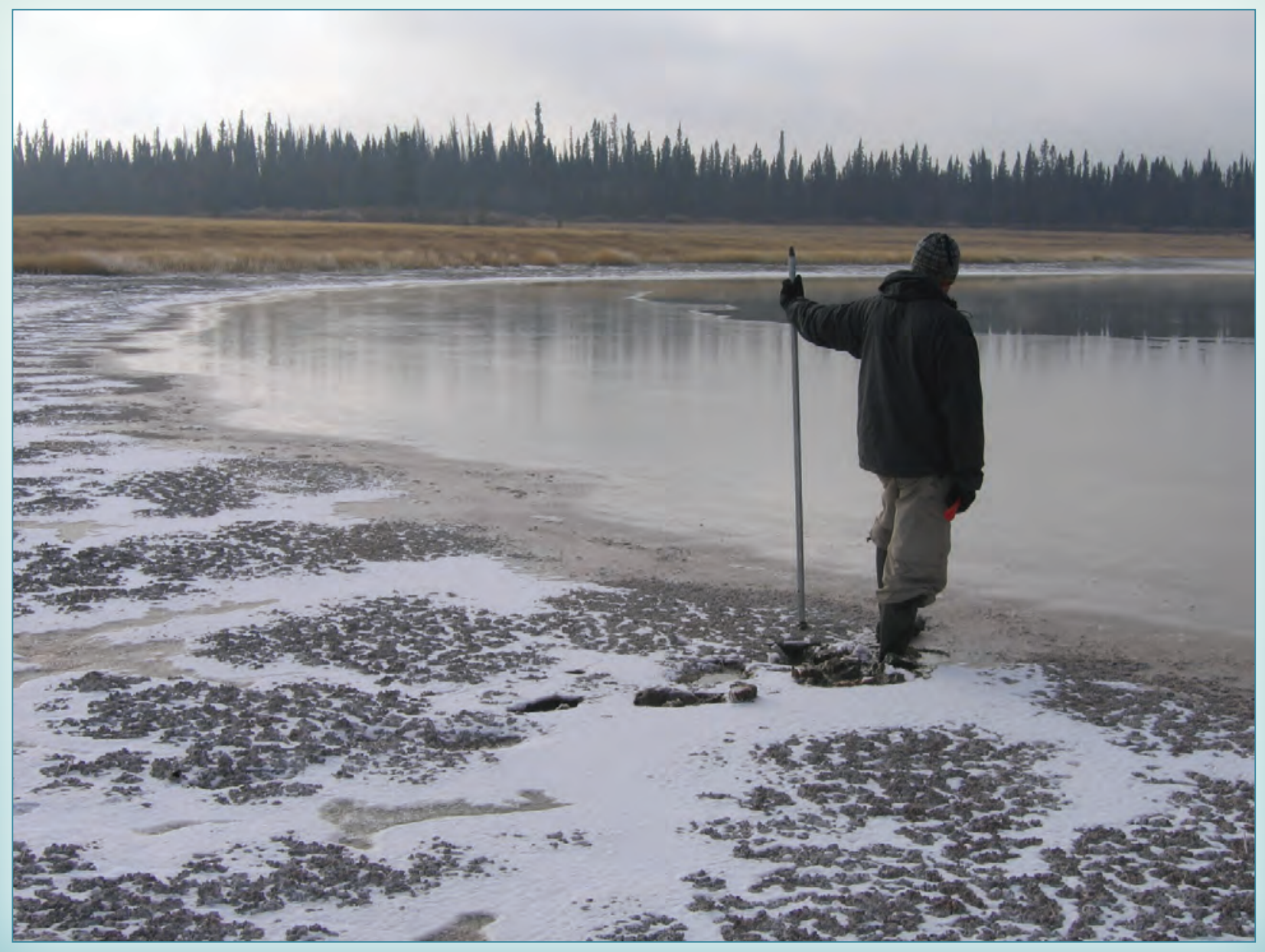

U.S. Geological Survey (USGS) hydrologist conducts research in Alaska. USGS scientists are investigating levels of avian influenza virus in groundwater and surface water (Haack and others, 2015; Hunt and others, 2014; Meixell and others, 2013). Photograph by the USGS. 
Proposed Action 3. Conduct experimental HPAl studies to understand the role of peridomestic wild birds in the movement, transmission, and evolution of these viruses.

The USGS will collaborate with the USDA to determine the role of peridomestic wild birds in spread, transmission, and maintenance of AI through experimental studies. When field research suggests a role for peridomestic birds, experimental research will be conducted in a high biocontainment laboratory to assess levels of HPAI virus shedding, morbidity, mortality, and transmission potential of these wild birds. The resulting information will be used to refine HPAI models by decreasing uncertainty and identifying alternative management strategies to reduce the economic impact of HPAI on poultry operations. The USGS recently published results from a study investigating the role of European starlings, invasive peridomestic birds, in HPAI dynamics (Hall and others, 2016).

Proposed Action 4. Conduct research to examine the role of non-avian peridomestic species in the movement and transmission of HPAI.

The USGS has begun pilot research with the USDA to coordinate HPAI research on non-avian peridomestic wildlife (raccoons and rodents) in the vicinity of affected poultry facilities. While there has been experimental evidence to suggest a role for small mammals in the movement and transmission of HPAI (Hall and others, 2008; Tejeda and others, 2015), additional species and pathways have yet to be investigated. Results of this research will be incorporated into management decisions and HPAI risk assessments (Science Goal 5).

\section{Objective 4. Determine implications of LPAI and HPAI exposure for wildlife populations.}

HPAI is primarily a disease of poultry, rarely impacting wild birds to a significant degree. However, there are a few wild bird species, such as raptors, that may develop neurological disease and die from HPAI. Enhanced knowledge of the avian immune response to these viruses and the underlying genetics will be used for risk assessments of population-level impacts on species of management and (or) conservation concern.

Proposed Action 1. Investigate population level impacts of HPAI exposure on Department of the Interior trust species.

The USGS will conduct a review of threatened and endangered species with known or likely susceptibility and (or) exposure to HPAI. In conjunction with experimental and field data, these analyses can be used to quantify possible population-level impacts of HPAI. This information will be shared with the USFWS for incorporation into species management plans.
Proposed Action 2. Determine the genetic factors associated with HPAI resistance and susceptibility.

The USGS will conduct comparative immunogenetic studies of wild birds that are resistant to HPAI (waterfowl) and those with known or suspected susceptibility to HPAI disease (raptors). Analyses of genomes and transcriptomes of uninfected and infected wild birds are known to provide insight into the immune response relative to HPAI (Huang and others, 2013). The USGS has conducted transcriptome research in wildlife species of management concern (Bowen and others, 2015a,b). Identification of biomarkers (immune gene transcription patterns), a non-invasive tool, will help natural resource managers identify species and populations that may be susceptible or resistant to HPAI disease when experimental studies are not feasible.

Proposed Action 3. Compare wildlife HPAl immune responses for targeted HPAl surveillance and management.

While many waterfowl infected by HPAI viruses may not show signs of disease, some wild birds show clear signs of morbidity and mortality. The neurological disease and resulting death observed in Canada geese (Pasick and others, 2007) and raptors (Hall and others, 2009; Kim and others, 2015) suggest there may be a different immune response to some HPAI viruses in these species. The USGS will collect baseline avian immunology data and conduct experimental research to determine the underlying immunological susceptibility of sensitive species to certain strains of HPAI. Understanding speciesspecific susceptibility and resistance is essential to efficiently design surveillance activities (Science Goal 1, Objective 2, Proposed Action 3) and management strategies for susceptible species of conservation concern (Science Goal 5, Objective 1).

\section{Science Goal 3: Characterize HPAI Viruses Circulating in Wildlife}

Research by the USGS and its partners has used AI genetic data to demonstrate the role of wild birds and their international migratory flyways in the dispersal of both LPAI and HPAI viruses (see highlight 4: Genetics of AI Viruses). In addition to host and environmental characteristics (Science Goal 2), HPAI dispersal potential depends upon the ecology and evolution of AI viruses (antigenic structure (HA and NA subtypes)), genetic diversity, virulence, host adaptation, reassortment rate, and dominant circulating genotype) (Dugan and others, 2008; Lee and others, 2015). Characterization of established and emerging strains of HPAI and co-occurring LPAI viruses will help determine how different HPAI strains persist and spread. Science Goal 3 data will be integrated into HPAI risk maps and models (Science Goal 5) to support AI management. 


\section{Plighlight 4: Genetics of Al Viruses}

The USGS conducts genetic analyses of AI viruses each year to determine the role of migratory birds in the dispersal of viruses and identify how viral communities are changing over time. This information is used to refine future surveillance efforts for North America and to inform biosecurity measures by U.S. poultry facilities. Viruses characterized in Alaska, Iceland, and along the U.S. Gulf Coast demonstrate that migratory bird flyways facilitate the movement of foreign-origin viruses into North America from Asia, Europe, and South America. Genetic analysis has determined pathways, timing, and mechanisms of transmission between species and regions, contributing to the design of HPAI surveillance strategies (Koehler and others, 2008; Pearce and others, 2009; Dusek and others, 2014; Ramey, Walther, and others, 2014; Lee and others, 2015; Ramey, Reeves, Sonsthagen, and others, 2015).

U.S. Geological Survey (USGS) biologist Lisa Pajot tests samples in a laboratory. As the lead Federal agency for wildlife disease surveillance, the USGS maintains specialized laboratories across the United States for research, diagnosis, and surveillance of wildlife pathogens. Photograph by the USGS.

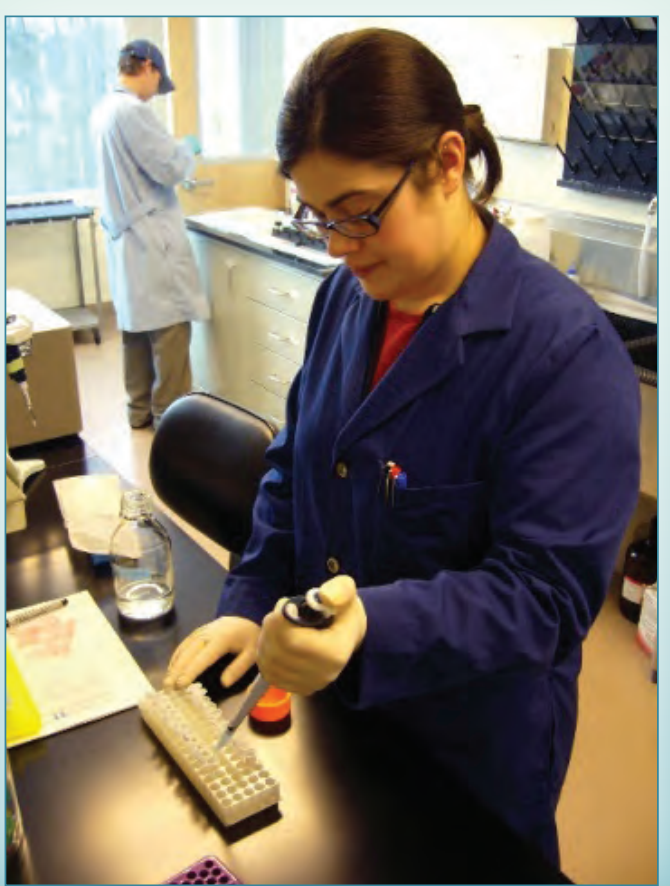

\section{Objective 1. Characterize Al viruses circulating in wild birds.}

AI viruses are designated as either LPAI or HPAI, depending upon virulence in poultry. These viruses are genetically diverse with numerous subtypes and molecular characteristics common to continental landmasses (North America, South America, Asia, and Europe). Genetic sequencing can be used to distinguish LPAI versus HPAI, Eurasian versus North American genetic components, and phylogenetic relationships. Thus, genetic data can be useful for understanding geographic origins, timing of emergence, persistence of genotypes, likely pathways of geographic dispersal, and viral exchange across the wild bird-poultry interface.

\section{Proposed Action 1. Characterize HPAl viruses in wild birds across North America.}

Through mutations and reassortment events, HPAI viruses will continue to change over time. The USGS will continue to analyze the genetic characteristics and changes in viral communities over time (Lee and others, 2015). Data on the ecology and evolution of these viruses will be used to determine pathogenicity in wild and domestic birds, dispersal potential, persistence, and similarities to HPAI viruses circulating in poultry.

\section{Proposed Action 2. Characterize LPAI viruses in wild birds across North America.}

The USGS will continue to describe the genetic diversity of LPAI viruses (Reeves and others, 2013; Ramey, Walther, and others, 2014). Genetics of LPAI viruses co-circulating with HPAI and their contribution to novel reassortant HPAI strains will be incorporated into models (Science Goal 5) that can contribute to Federal, State, and tribal AI management decisions.

\section{Proposed Action 3. Characterize LPAI and HPAI strains in} peridomestic wild birds near poultry operations.

While identification of circulating HPAI strains is necessary for poultry risk assessments, characterization of LPAI strains is important for public health risk assessments. Human influenza pandemic viruses have had genes from LPAI strains (for example, 1918 Spanish Flu H1N1, 1957 H2N2, and 1968 H3N2) (Horimoto and Kawaoka, 2001). The USGS will work with the USDA to assess the genetics of LPAI and HPAI strains circulating in peridomestic wild birds (such as starlings and finches) near poultry operations. This data will be integrated into risk assessments (Science Goal 5) and communicated to resource managers who make AI-relevant decisions. 


\section{Objective 2. Characterize Al viruses circulating in wild mammals.}

Determination of persistence and evolution of HPAI in North America may require sampling and viral characterization of non-traditional species. Such investigations will inform biosecurity and human health concerns. The 2009 swine flu pandemic was a new strain of H1N1 that resulted from a triple reassortment of bird, swine, and human flu viruses (Smith and others, 2009). Small mammal species are common in and around areas frequented by wild birds and domestic flocks and may serve as important bridge species between wildlife and poultry. Field and laboratory research can determine the role of non-avian wildlife (such as rodents and feral swine) in persistence or transmission of HPAI viruses in North America.

Proposed Action 1. Characterize Al viruses circulating in peridomestic mammals near poultry operations.

The USGS will collaborate with the USDA to analyze the genetics of AI isolates from peridomestic wildlife (raccoons, rodents) to understand their potential role as bridge vectors (Flint and others, 2015). Research has documented a potential role for raccoons (Hall and others, 2008) and rodents (Tejeda and others, 2015) in HPAI dynamics. Genomic analyses will be integrated into HPAI risk assessments and models (Science Goal 5).

Proposed Action 2. Characterize Al viruses circulating in feral swine.

The USGS will work with the USDA-APHIS National Feral Swine Damage Management Program to examine the role of feral swine in the generation and maintenance of novel influenza viruses. The genetics of virus isolates will be analyzed and compared with wild bird, poultry, and human isolates to assess the role of feral swine in HPAI reassortment. Feral swine share habitat with waterfowl, prey on and scavenge dead birds, are highly mobile, and come into contact with humans. Swine can harbor mixed influenza infections and promote genetic reassortment between avian, human, and swine influenza (Smith and others, 2009). Feral swine populations in the U.S. are expanding in both numbers and range (Bevins and others, 2014), and they are increasingly coming into contact with waterfowl, humans, and agricultural operations. While they are known to spread domestic swine and human influenza viruses (Feng and others, 2014; Sun and others, 2015), their role in HPAI dynamics is unclear. Results of these genomic analyses will be incorporated into risk assessments and models (Science Goal 5).

\section{Objective 3. Characterize HPAI viruses circulating outside North America and on the continental fringes with potential for introduction to North America.}

East Asia has recently been the epicenter of most HPAI H5 viral strains. HPAI H5N1 first emerged in 1996 and remained within Asia until 2005 when it began to spread globally, though never detected in North America. HPAI H5N8 spread much faster; after first emerging in Asia in January 2014, viruses spread to Europe and North America in the fall and early winter of the same year (Ip and others, 2015; Lee and others, 2015). In North America, H7 LPAI viruses emerge each spring in waterfowl that migrate north into the U.S. from central and South America (Ramey, Poulson, and others, 2014). Highly pathogenic H7 viruses that evolved from precursor low pathogenic $\mathrm{H} 7$ viruses have caused outbreaks of disease in poultry in Mexico (Kapczynski and others, 2013). Novel HPAI and LPAI strains will likely continue to emerge globally, each with different levels of impact to poultry and humans and different abilities to spread.

\section{Proposed Action 1. Characterize Al viruses circulating in wildlife outside of North America.}

The USGS will conduct research and surveillance with international collaborators in Asia, Europe, and South America to identify emergent LPAI and HPAI viruses with potential to spread to U.S. poultry and wildlife. This research will benefit the U.S. and our international partners (Global Health Security Agenda (GHSA) infectious disease detection). The USGS currently partners with scientists in Russia, China, Japan, and Iceland on AI research (Yamaguchi and others, 2010; Prosser, Cui, and others, 2011; Dusek and others, 2014; Samuel and others, 2015). Genetic data from this research network will be used to refine surveillance activities (Science Goal 1) and provide information for models (Science Goal 5) that can be used to improve biosecurity measures for the poultry industry.

\section{Proposed Action 2. Characterize Al viruses on continental fringes of North America.}

The USGS will determine genetic diversity of AI viruses within avian communities on the margins of North America (Alaska, U.S. Gulf Coast, and Atlantic Coast) that are identified as likely areas of introduction for foreign-origin viruses. Genetic analyses from these locations will test hypotheses regarding which avian species are more likely to bring foreign-origin viruses to the U.S., and the results will be integrated into risk assessments for AI management and control efforts (Science Goal 5). 


\section{Science Goal 4: Understand Implications of Avian Ecology on HPAI Spread}

USGS research on the long distance, seasonal migratory behavior of wild birds and their unique ecologies has demonstrated its importance in HPAI spread within and across continents (see appendix 2 and highlight 5: Merging Wild Bird Migration and Disease Ecology). Outbreaks of HPAI H5N8 in Korea have corresponded with migratory bird movements, where the disease has not occurred in summer when birds were on northern breeding areas, but returned during the fall migration in 2014 and 2015 (Jeong and others, 2014). Understanding how the disease is maintained and transmitted within wild bird communities relative to the ecology of wild birds is necessary (Yasué and others, 2006). Additionally, recent movement models developed by USGS scientists have identified associations between key avian staging areas, stopover sites, and migration corridors and AI spread in Asia (Tian and others, 2015). This quantitative movement data can be supplemented by research on the intercontinental genetic structure and gene flow of wild birds (Miller and others, 2015). Elucidation of wild bird movements, population genetics, and trophic interactions in North America will inform risk assessment models for susceptible poultry and birds of prey (Science Goal 5).

\section{Objective 1. Map spatial and temporal distributions of wild and domestic avian populations for risk model development.}

Spatial and temporal distributional data on wild avian populations is available through existing bird surveys (USFWS, Canadian Wildlife Service) and USGS avian ecology international and national research (for example, Gaidet and others, 2010; Hill and others, 2012; Capelle and others, 2014). Digitized data from these sources can be mapped to support risk assessment models and forecast avian community interactions that facilitate HPAI spread. Similarly, this wild bird data can be mapped with USDA and State poultry operations data to facilitate modeling the risk of HPAI spread from wild birds to poultry.

Proposed Action 1. Develop wild and peridomestic bird distribution models as inputs for disease risk assessments.

Using existing survey data (for example, USGS bird banding data, USFWS aerial survey information, and Christmas Bird Count), the USGS will develop nationwide gridded models for wild and peridomestic bird species as potential AI vectors. This effort will identify important informational gaps that should be addressed to understand the spread and persistence of AI between wild and peridomestic species. These models can serve as inputs for HPAI risk assessments (Science Goal 5).
Proposed Action 2. Develop high resolution models of poultry densities as inputs for disease risk assessments.

The Congressional Research Service estimated economy-wide losses of 3.3 billion dollars (Greene, 2015) and the USDA has reported that over 50 million chickens and turkeys were dead or culled as a result of the 2014-2015 HPAI outbreak. Understanding where different poultry farms (species, meat versus egg-laying, biosecurity level, facility size, etc.) are spatially located in relation to wild bird densities is an important component of HPAI risk models. In collaboration with the USDA, the USGS will develop highresolution gridded models as inputs for HPAI risk assessments (Science Goal 5).

Proposed Action 3. Examine the influence of climate change on bird migration and its implications on $\mathrm{Al}$ dynamics.

Timing of bird migration is influenced by various factors such as temperature, plant phenology, and insect emergence. As climate varies, cascading effects may lead to changes in the predictable migration patterns of birds. This may impact reproductive success, survival, and AI forecasting. The USGS will examine the influence of climate change on migratory patterns of AI wild bird reservoirs for the development of predictive models (Science Goal 5).

\section{Objective 2. Address Al-relevant information gaps in avian migratory connectivity data.}

Existing survey and movement data that define avian migratory connectivity have information gaps that, once filled, could help elucidate AI virus spread and reassortment, leading to improved spatial allocation of HPAI management resources. The USGS will evaluate current databases and strategies for collecting avian distribution and movement data in order to address these gaps. The USGS will use a multifaceted approach to determine avian distribution, movement, and biological factors that correlate with AI distribution and reassortment.

Proposed Action 1. Develop quantitative flyway maps of avian $\mathrm{Al}$ reservoir species.

Building on current knowledge, the USGS will execute studies using satellite and Global Positioning System (GPS) telemetry to precisely identify movement and distribution patterns of avian species involved in AI spread between continents and its persistence in North America (see appendix 2). The USGS recently used dynamic Brownian bridge movement models to enhance traditional qualitative flyway maps with more quantitative data regarding sub-population stopover and staging sites along the Central Asian and East Asian-Australasian flyways (Palm and others, 2015). Use of these tools along North American flyways will enhance our 


\section{Heighlight 5: Merging Wild Bird Migration and Disease Ecology}

The USGS has determined that wild bird movements are important to the spread and distribution of AI viruses (Takekawa and others, 2010a; Lee and others, 2015). USGS research demonstrated that wild birds passed through an active outbreak area of Asian HPAI H5N1 and continued on with long-distance migrations to northeastern Russia (Yamaguchi and others, 2010). The USGS and collaborators found that this same migratory flyway was the probable source of the 2015 HPAI H5N8 virus that impacted the United States (Lee and others, 2015). Overlapping migratory bird populations from different continents at stopover, breeding and wintering areas offer opportunities for viral exchange (Flint and others, 2009; Dusek and others, 2014), and subpopulations of different species can distribute AI viruses throughout a shared breeding area (Reeves and others, 2013). USGS-led research has also identified that infection rates of migratory birds differ between breeding, migration, and wintering areas, suggesting that AI viral exposure is occurring during several phases of the annual cycle (Samuel and others, 2015) and different AI viruses are carried by bird species at different times of the year (Ramey, Poulson, and others, 2014).

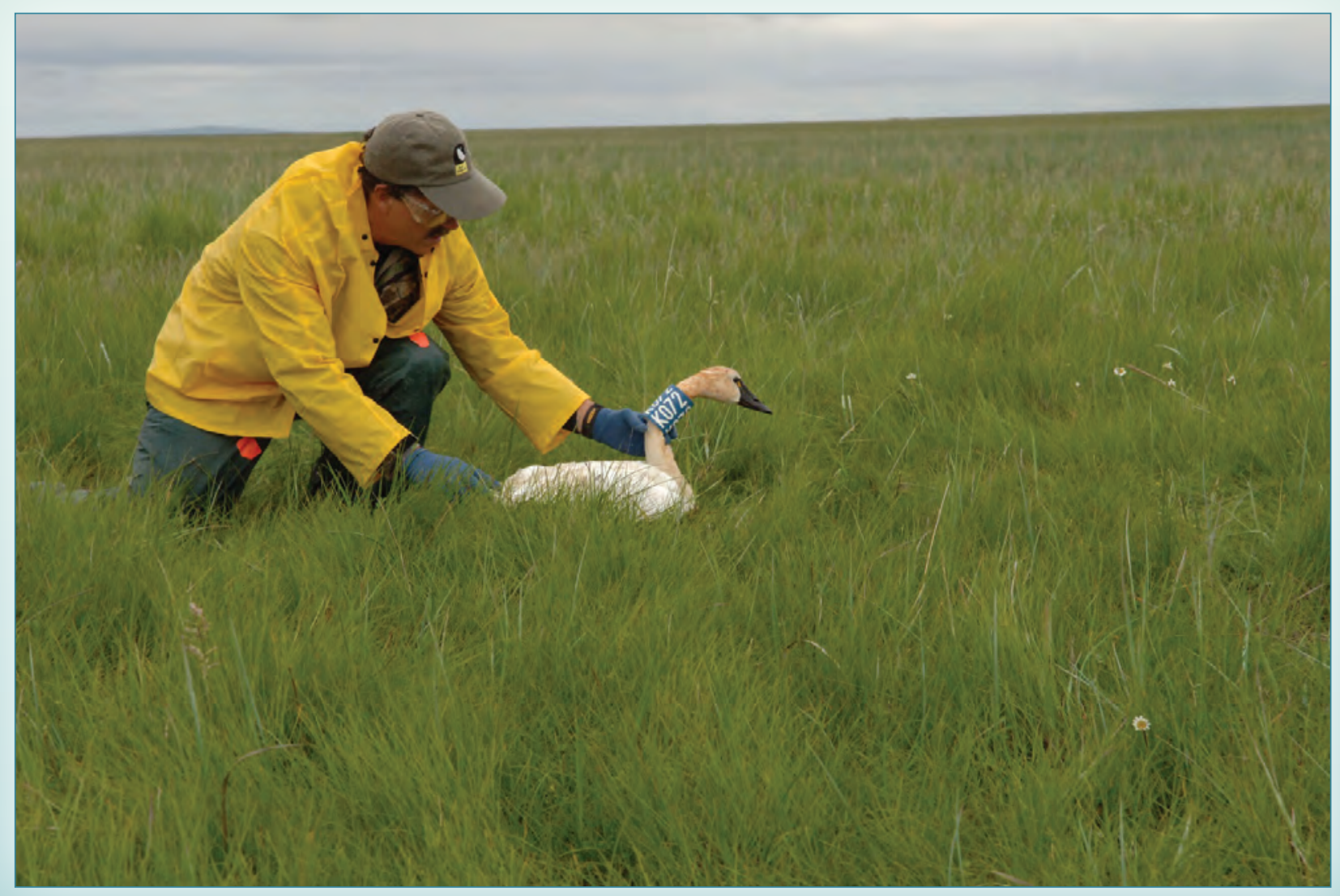

U.S. Geological Survey (USGS) biologist Craig Ely releases a marked Tundra Swan in western Alaska. USGS scientists and collaborators have investigated the dynamics of avian influenza exposure in Alaskan Tundra swan populations (Reeves and others, 2013; Wilson and others, 2013). Photograph by the USGS. 
understanding of spatial relationships between migration corridors and HPAI outbreaks (Takekawa and others, 2010a).

This migratory data will be incorporated into HPAI forecasting models (Science Goal 5).

\section{Proposed Action 2. Determine population connectivity of avian Al reservoir species through genetic analyses.}

Where needed, the USGS will use molecular genetic analyses to determine the population connectivity of migratory birds known to carry AI viruses (Flint and others, 2009). The USGS has used genetic data to identify long-term patterns of connectivity among populations (Miller and others, 2015; see appendix 2). Inferences regarding population connectivity can be related back to HPAI models (Science Goal 5) to determine relationships between wild bird populations and AI occurrence and reassortment. Avian movement patterns and distributions can also be compared to covariates (chronology, climatic conditions, landscape features, and non-avian AI detections) to refine understanding of links between avian population connectivity and the dynamics of viral transmission and spread.

\section{Proposed Action 3. Characterize landscape connectivity} between avian $\mathrm{Al}$ reservoirs and wild birds susceptible to HPAl disease.

Currently, HPAI-related mortality in the U.S. has been associated with a few species (such as bald eagles and peregrine falcons). Internationally, however, other species have died from HPAI (for example, bar-headed geese and black-necked cranes) (Takekawa and others, 2010b, 2013). The USGS will collaborate with USFWS to use bird survey, telemetry, and genetic data (see appendix 2) to characterize landscape connectivity of HPAI-susceptible birds and AI reservoir species at breeding and wintering sites in the United States. Models of this connectivity data (Science Goal 5) will be shared with natural resource managers (USFWS) for incorporation into species management plans.

\section{Objective 3. Investigate HPAI transmission in avian communities and the impact of HPAI on avian populations.}

Little is known about how ecological communities and food webs shape the transmission and spread of AI (Caron and others, 2012). Sampling of multiple food web vectors will establish the primary routes of transmission and identify the most susceptible species (avian and non-avian) along with the potential for transfer into related, weakly linked food webs. While AI viruses are known to affect waterfowl body weight (Kuiken, 2013), little is known of AI effects on avian fitness (reproductive success, survival) and populations.

\section{Proposed Action 1. Determine HPAl transmission pathways within ecological communities.}

The USGS will sample other birds in the avian community for AI simultaneously with targeted dabbling ducks. This action will complement wild bird surveillance efforts (Science Goal 1). Habitat loss and degradation as well as expansion of certain populations (for example, snow geese, Canada geese) have shifted trophic dynamics (such as the exploitation of agricultural crops) and community interactions (Jefferies, 2000). The impacts of these shifts on AI dynamics are unknown. Adopting a sampling design that includes different age groups and banded adults from the wintering and breeding grounds will further elucidate mechanisms that help spread disease within communities. The design of these AI community studies can be refined and standardized to best utilize life history and trophic dynamics data for risk models (Science Goal 5).

\section{Proposed Action 2. Assess impact of HPAI on North American avian populations.}

The USGS will collaborate with natural resource managers to assess the impact of HPAI on wild bird populations. AI avian sampling occurs with bird banding. Results of AI surveillance (Science Goal 1) will be combined with banding, survey, and telemetry data (see appendix 2) for statistical analyses of population and reproductive trends. This action will examine the potential trade-offs of HPAI infections on reproductive success and survival.

\section{Science Goal 5: Develop HPAI Forecasting and Decision-Making Tools}

The USGS has the expertise to provide formal decision analytical consulting to partner management agencies (see appendix 2). Decision analytic scientists can facilitate stakeholder identification of what scientific information is needed to help make better decisions about the response to HPAI. Identification of key decision points and critical information gaps will guide prioritization of research in Science Goals 1-4 and serve as the basis for the development of models and data visualization tools (see appendix 2 and highlight 6: Risk Assessment Models). This process is most effective if established early in preparing for a disease response so that the science can be directed by the needs of management agencies. This iterative process allows the science to be driven directly by management needs and adapted as new information is obtained or as the situation evolves as is often the case with AI viruses.

Epidemiological modeling enhances our understanding of disease dynamics and influences the response to diseases (for 
example, measles, dengue, and Ebola). Rather than just developing models hypothesized to inform the disease response, HPAI models will be jointly developed with scientists and decision makers to ensure relevance and direct applicability to $\mathrm{AI}$ management and decision-making.

Building disease-specific models requires detailed information on key risk factors that can be included as model components. Over the past 16 years, a large body of knowledge has accumulated from the HPAI H5N1 experience in Eurasia and Africa, and North American AI surveillance. The USGS will harness knowledge from past and current HPAI research to provide decision support to management agencies, develop HPAI risk assessment and predictive models, and provide online data visualization tools.

\section{Objective 1. Provide decision support to management agencies.}

The field of decision analysis provides a wealth of tools to structure difficult decisions, elicit diverse management objectives, integrate relevant scientific knowledge, craft effective alternative strategies, and ultimately choose an optimal strategy. The interaction with decision makers also helps scientists identify key and common uncertainties to address in their research questions. The USGS has expertise in all aspects of decision analysis (Runge, 2011; Shea and others, 2014; Probert and others, 2015). Central to formal decision analysis is the understanding that a decision requires the integration of scientific assessment with policy and values judgment. An agency charged with management of disease has an enabling mandate that helps determine both the desired outcomes of management and the tools the agency has at its disposal. Additional input about the desired management outcomes can come from stakeholder analysis and consulting. In this context, the scientific task is to evaluate the available management actions in concert with the desired outcomes, and provide methods for identifying the most effective strategy. Taken from this applied science perspective, many aspects of scientific research may change their focus. For instance, decision analysts can use the value of information theory to assess whether the reduction of scientific uncertainty through additional research is valuable to a decision maker. The value of research depends on if the associated gain in knowledge would shift the decisionmaker's course of action and expected outcomes. Likewise, to a decision maker, the purpose of surveillance or monitoring is to provide critical information that influences when and what action to take; there are well-established decision analytical tools for evaluating these types of questions that are useful to decision makers and researchers. With regard to HPAI, the USGS has an opportunity to offer expertise in decision analysis to partner management agencies, and use this partnership to optimize future surveillance design and refine future research agendas.

\section{Proposed Action 1. Work with management agencies to develop a quality HPAI decision-making framework.}

USGS decision analytic scientists will consult with Federal and State management agencies to understand their information needs and implement an adaptive management approach to HPAI where applicable. The USGS has expertise, and can develop greater capacity, to provide formal decision analytical consulting to partner management agencies involved in the management of AI. First, the USGS will identify Federal, State, and tribal management agencies that are, or could be, taking actions to reduce the spread or mitigate the impacts of HPAI. Second, the USGS would need to work with those agencies to understand the types of actions they can take, the regulatory or legal context under which they take them, and the information needs they have in making those decisions. Third, through individual consulting projects, the USGS could help partner management agencies identify the context of their decisions, articulate their management objectives and performance metrics, and craft the array of alternative strategies for consideration. This decision-framing sets the stage for robust assessment of the management strategies and methods to identify optimal strategies, taking account of uncertainty and the opportunity for adaptive management. This sort of decision analytical process can support interactions between management and science agencies, help management agencies choose an optimal strategy, and help communicate the decision process to the public.

\section{Proposed Action 2. Synthesize HPAI decision analyses from different management agencies to identify common information gaps and critical uncertainties.}

The USGS will conduct a meta-analysis of the HPAI decision frameworks developed in Proposed Action 1. As experience grows working with individual management agencies on particular decision contexts related to HPAI, a synthesis of those analyses would allow broader insights that could affect the direction of future USGS efforts. In particular, sensitivity analysis can be used to identify (1) which monitoring variables are critical for State-dependent decisions; (2) which uncertainties impede the choice of a preferred alternative and would be valuable to resolve through research or adaptive management (value-of-information analysis); and (3) which outcomes reflect common management goals and should be monitored to evaluate success. These analyses can be completed for individual projects, but the power of a meta-analysis would allow identification of those research and monitoring activities that would benefit multiple management partners. 


\section{Highlight 6: Risk Assessment Models}

Understanding the spatial and temporal interface between wild and domestic bird populations, from which these viruses emerge, is fundamental to taking action. The USGS has led the development of visual representations of data from China that can demonstrate how the spread of AI viruses is influenced by environmental and human factors (Prosser and others, 2015; Prosser, Wu and others, 2011). This AI Transmission Risk Model web application depicts the intricate connections among 16 layers of administrative, environmental, and economic data in an application that runs inside a web browser. A zoom-able map has a sidebar showing the legend, and the layers can be turned on and off. The map also has a brush-enabled outbreak event timeline that is color-coded for serotype, giving users the opportunity to follow the history of the disease both spatially and temporally. Future models for the U.S. (Science Goal 5, Objective 3, Proposed Action 2) will show the potential risk of transmission of AI between wild and domestic birds, the presence and density of poultry production, and the distribution of wild bird species in the area of poultry, all of which may influence outbreaks.

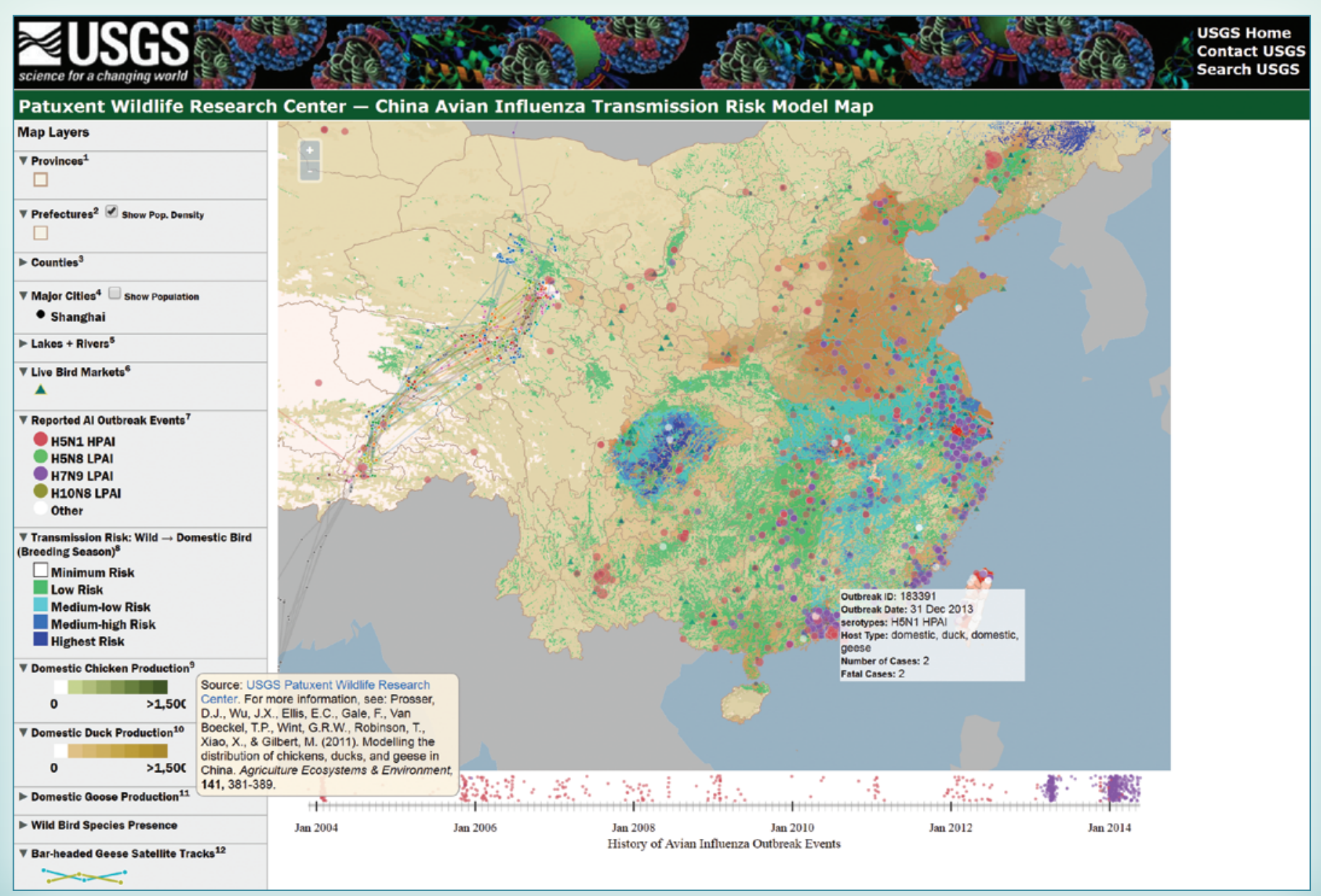

An example of a decision-making tool from Science Goal 5. In collaboration with the Food and Agriculture Organization, the U.S. Geological Survey has examined the risk of HPAI moving between wild birds and poultry in China. Similar risk models are being developed for the United States. Figure from http://www.pwrc.usgs.gov/ai/ (to view Web page use Google Chrome browser). 


\section{Proposed Action 3. Refine HPAI research priorities based on management partner needs.}

Research on HPAI by the USGS will be aimed at supporting the needs of management agencies. Adaptive management (Proposed Action 1) may identify new HPAI information gaps. The outcomes of the synthesis in Proposed Action 2 can be used to further refine USGS research priorities and decisionsupport tools (models, data visualization tools) to meet the needs of management agencies.

\section{Objective 2. Develop HPAl risk assessment and predictive models.}

Predictive spatial modeling can be used to identify priority areas for pre-outbreak disease surveillance and postoutbreak response. This type of information can be valuable to partner agencies as they mount rapid response actions using limited resources for sampling wild birds and poultry. Additionally, identifying areas of increased transmission risk between wild and domestic populations will be important for managing wildlife populations (including threatened species) and implementing poultry biosecurity measures. In an adaptive manner, cursory models can be improved with the addition of data from mechanistic studies. Objective 2 actions will be prioritized based on partner-identified information gaps and critical uncertainties (Objective 1).

\section{Proposed Action 1. Develop dynamic occupancy models to estimate probabilities of Al occurrence.}

Dynamic models estimate rates of colonization (disease presence) and extinction (disease absence). Such models are valuable decision support tools for estimating the probability of AI occurrence in a spatial manner. Using established and new datasets (Science Goals 1-4) on AI occurrence and spatial variables (proximity to and number of neighboring AI locations in wild birds and poultry, habitat, and season), the USGS will develop predictive models of AI movement by wild birds. Because not all States and poultry operations have been impacted by HPAI, these predictive models can support proactive AI management efforts.

\section{Proposed Action 2. Conduct a meta-analysis of existing Al} mechanistic models.

The USGS will conduct a meta-analysis of existing AI mechanistic models. There is a growing body of literature related to dynamic modeling of AI that can be drawn upon to develop a mechanistic disease framework for newly emerged HPAI. This work would entail collating existing information to parameterize a mechanistic model and applying the model to a Bayesian statistical framework. The model would enhance our understanding of the epidemiology of HPAI and support AI management decisions.

\section{Proposed Action 3. Develop geospatial models of HPAI} transmission risk at the wild-to-domestic bird interface.

The USGS will collaborate with the USDA to develop virus-specific (H5N8 or H5N2) spatial transmission risk models that focus on the interface between wild birds and poultry. Development of these models will be important to the poultry industry, wildlife managers, as well as decision-makers who are involved in preparedness and response planning for HPAI.

\section{Proposed Action 4. Develop Landsat-based HPAI risk maps.}

The USGS will collaborate with the USDA to develop habitat-based risk maps from geospatial HPAI occurrence data and Landsat, which provides continuously updated land imagery from space. Satellite imagery can play a key role in disease forecasting (Ford and others, 2009). Geospatial data on HPAI occurrence in wild birds and poultry will serve as the foundation for novel Landsat-based identification of similar habitats that are important for AI transmission. To understand future transmission risk, this data will be critical to project changes in transmission locations due to land use modifications and climate change. This information can help identify poultry facilities and wildlife habitats that have a high risk for HPAI outbreaks.

\section{Proposed Action 5. Develop hydrologic HPAl risk maps.}

The USGS will partner with the USDA to develop hydrologic HPAI risk maps from HPAI occurrence data and identification of locations with similar water characteristics and flows. Previous studies have shown that AI viruses can persist in wet environments under certain conditions (Brown and others, 2007), and that environmental transmission may be a key factor in the overall spread and persistence of AI viruses (Rohani and others, 2009). This action proposes to develop risk map layers specifically for the water environment based on environmental conditions and hydrologic flow regimes from potential source locations such as poultry farms or natural areas containing large congregations of wild birds.

Proposed Action 6. Develop models of HPAI transmission risk for avian communities.

Applying data from avian distribution and migratory connectivity research (Science Goal 4), the USGS will model the risk of HPAI movement to new areas via wild birds. Wintering grounds in California's Central Valley have been identified as high risk areas for HPAI transmission (Hill and others, 2012). These models will identify other high risk areas for AI transmission within and between resident and migratory wild populations in North America. This knowledge will be shared with partners to support HPAI management of poultry and HPAI-susceptible wild birds. 
Objective 3. Develop online HPAI data visualization tools.

Effective and efficient preparedness and response is aided greatly by having knowledge of what data already exists and having a platform for viewing these data in an integrated setting and decision context to know which information will be useful to managers. Effective cataloging of data and products as well as hierarchical dissemination through appropriate channels is key to reducing duplication of effort. This objective is focused on developing collaborative databases and online HPAI data visualization tools for resource managers. Input from management agencies (Objective 1) will guide the development of these tools as the USGS aims to meet partner needs.

Proposed Action 1. Improve existing collaborative databases to store historical and future HPAI data.

In support of the 2006 U.S. AI Interagency Strategic Plan, an online national database (Highly Pathogenic AI Early Detection Data System, or HEDDS) was developed to manage animal and specimen collection data on AI from multiple agencies. With USDA collaboration, recent advances in technology will be used to refine this system for increased ease of data entry, data export, security for users with sensitive data, and data analyses features. This improved database will provide a comprehensive view of national sampling efforts for both LPAI and HPAI from 2006 to present providing situational awareness and data availability for both decisionmaking agencies and researchers.

\section{Proposed Action 2. Develop an HPAI data visualization} tool.

The USGS will develop an online HPAI data visualization tool for partners making HPAI management decisions. In response to HPAI H5N1, the USGS developed a data visualization tool (http://www.pwrc.usgs.gov/ai/) to facilitate viewing of spatial datasets and modeling products pertinent to H5N1 in Asia (see highlight 6: Risk Assessment Models). This action will build upon the current tool and provide a platform for viewing data related to the current HPAI situation in the United States. The USGS will work with the USDA to include reported AI outbreaks in poultry, detections in wild birds, surveillance sampling, environmental risk factors, and developed models (for example, spatial risk models).

\section{Acknowledgments}

This report and writing team were supported by the U.S. Geological Survey Ecosystems Mission Area. The writing team thanks the Ecosystems Mission Area for sponsoring an essential writing team meeting on September 9-10, 2015, in Reston, Va. The authors thank Cynthia S. Kolar, Evan H. Grant, and Mona Khalil for their reviews that significantly enhanced this report. We also thank Garth Herring, Collin A. Eagles-Smith, and Patricia Bright for contributing their time to the conference calls for the strategy developed in this report.

\section{References Cited}

Abd-Elmaksoud, S., Spencer, S.K., Gerba, C.P., Tamimi, A.H., Jokela, W.E., and Borchardt, M.A., 2014, Simultaneous concentration of bovine viruses and agricultural zoonotic bacteria from water using sodocalcic glass wool filters: Food and Environmental Virology, v. 6, no. 4, p. 253-259, accessed February 6, 2016, at http://dx.doi.org/10.1007/ s12560-014-9159-z.

Almberg, E.S., Cross, P.C., Johnson, C.J., Heisey, D.M., and Richards, B.J., 2011, Modeling routes of chronic wasting disease transmission; Environmental prion persistence promotes deer population decline and extinction: PLoS ONE, v. 6, no. 5, 11 p., accessed February 6, 2016, at http://dx.doi. org/10.1371/journal.pone.0019896.

Bevins, S.N., Pedersen, K., Lutman, M.W., Gidlewski, T., and Deliberto, T.J., 2014, Consequences associated with the recent range expansion of nonnative feral swine: BioScience, v. 64, no. 4, p. 291-299, accessed June 22, 2016, at http://dx.doi.org/10.1093/biosci/biu015.

Borchardt, M.A., Spencer, S.K., Kieke, B.A., Jr., Lambertini, E., and Loge, F.J., 2012, Viruses in nondisinfected drinking water from municipal wells and community incidence of acute gastrointestinal illness: Environmental Health Perspectives, v. 120, no. 9, p. 1,272-1,279, accessed February 6, 2016, at http://dx.doi.org/10.1289/ehp.1104499.

Bowen, L., Miles, A.K., Drake, K.K., Waters, S.C., Esque, T.C., and Nussear, K.E., 2015a, Integrating gene transcription-based biomarkers to understand desert tortoise and ecosystem health: EcoHealth, v. 12, no. 3, p. 501-512, accessed February 6, 2016, at http://dx.doi.org/10.1007/ s10393-014-0998-8.

Bowen, L., Miles, A.K., Stott, J., Waters, S., and Atwood, T., 2015b, Enhanced biological processes associated with alopecia in polar bears (Ursus maritimus): Science of The Total Environment, v. 529, p. 114-120, accessed February 6, 2016, at http://dx.doi.org/10.1016/j.scitotenv.2015.05.039. 
Bradbury, K.R., Borchardt, M.A., Gotkowitz, M., Spencer, S.K., Zhu, J., and Hunt, R.J., 2013, Source and transport of human enteric viruses in deep municipal water supply wells: Journal of Environmental Science and Technology, v. 47, no. 9, p. 4,096-4,103, accessed February 6, 2016, at http:// dx.doi.org/10.1021/es400509b.

Bradford, S.A., Morales, V.L., Zhang, W., Harvey, R.W., Packman, A.I., Mohanram, A., and Welty, C., 2013, Transport and fate of microbial pathogens in agricultural settings: Critical Reviews in Environmental Science and Technology, v. 43, no. 8, p. 775-893, accessed February 6, 2016, at http://dx.doi.org/10.1080/10643389.2012.710449.

Brown, J.D., Swayne, D.E., Cooper, R.J., Burns, R.E., and Stallknecht, D.E., 2007, Persistence of H5 and H7 avian influenza viruses in water: Avian Diseases, v. 51, p. 285-289, accessed February 6, 2016, at http://naldc.nal. usda.gov/download/10459/PDF.

Brown, J.D., Stallknecht, D.E., Lebarbenchon, C., and Swayne, D.E., 2014, Survivability of Eurasian H5N1 highly pathogenic avian influenza viruses in water varies between strains: Avian Diseases, v. 58, no. 3, p. 453-457, accessed February 6, 2016, at http://dx.doi.org/10.1637/10741120513-ResNote.1.

Cappelle, J., Zhao, D., Gilbert, M., Nelson, M.I., Newman, S.H., Takekawa, J.Y., Gaidet, N., Prosser, D.J., Liu, Y., Li, P., Shu, Y., and Xiao, X., 2014, Risks of avian influenza transmission in areas of intensive free-ranging duck production with wild waterfowl: EcoHealth, v. 11, no. 1, p. 109-119, accessed February 6, 2016, at http://dx.doi. org/10.1007/s10393-014-0914-2.

Caron, A., de Garine-Wichatitsky, M., Ndlovu, M., and Cumming, G.S., 2012, Linking avian communities and avian influenza ecology in southern Africa using epidemiological functional groups: Veterinary Research, v. 43, no. 1, p. 1-11.

Cronin, J.P., Han, B.A., Keesing, F., Kilpatrick, A.M., Metcalf, C.J.E., and Welsh, M.E., 2012, Towards trait-based disease ecology; Integrating theory and data across kingdoms: Bulletin of the Ecological Society of America, v. 93, p. 95-99.

Cronin, J.P., Rua, M.A., and Mitchell, C.E., 2014, Why is living fast dangerous? Disentangling the role of resistance and tolerance of disease: The American Naturalist, v. 184, no. 2 , p. 172-187, accessed February 6, 2016, at http://dx.doi. org/10.1086/676854.

Cross, P.C., Caillaud, D., and Heisey, D.M., 2012, Underestimating the effects of spatial heterogeneity due to individual movement and spatial scale; Infectious disease as an example: Landscape Ecology v. 28, no. 2, p. 247-257, accessed February 6, 2016, at http://dx.doi.org/10.1007/ s10980-012-9830-4.
Dalton, M.S., Stewart, L.M., and Ip, H.S., 2009, Occurrence of viable avian influenza virus in water and bed sediments from selected water bodies along the Atlantic flyway, February and May 2006 and January 2007: U.S. Geological Survey Open-File Report 2009-1161, 12 p. [Also available at https://pubs.er.usgs.gov/publication/ofr20091161.]

De La Cruz, S.E.W., Takekawa, J.Y., Wilson, M.T., Nysewander, D.R., Evenson, J.R., Esler, D., Boyd, W.S., and Ward, D.H., 2009, Spring migration routes and chronology of surf scoters (Melanitta perspicillata); A synthesis of Pacific Coast studies: Canadian Journal of Zoology, v. 87, no. 11, p. 1,069-1,086, accessed April 6, 2016, at http://www.nrcresearchpress.com/doi/abs/10.1139/z09-099\#.VwUoUuIrJaR.

Densmore, C., Prosser, D., Iwanowicz, D., Ottinger, C., Iwanowicz, L., Hindman, L., McLaughlin, S., Driscoll, C., Whitbeck, M., and Bessler, A., 2016, Avian influenza virus in the aquatic environment; Biosurveillance using potential biotic and abiotic reservoirs [abs.]: Abstract for presentation at the 6th North American Ornithological Conference [NAOC], Washington, D.C., August 16-20, 2016, accessed August 12, 2016, at http://naoc2016.com/NAOC-MediaKit/Abstract_Book.pdf.

Domanska-Blicharz, K., Minta, Z., Smietanka, K., Marché, S., and van den Berg, T., 2010, H5N1 high pathogenicity avian influenza virus survival in different types of water: Avian Diseases, v. 54, supplement 1, p. 734-737, accessed February 6, 2016, at http://dx.doi.org/10.1637/8786-040109-ResNote.1.

Dugan, V.G., Chen, R., Spiro, D.J., Sengamalay, N., Zaborsky, J., Ghedin, E., Nolting, J., Swayne, D.E., Runstadler, J.A., Happ, G.M., Senne, D.A., Wang, R., Siemons, R.D., Holmes, E.C., and Taubenberger, J.K., 2008, The evolutionary genetics and emergence of avian influenza viruses in wild birds: PLoS Pathogens, v. 4, no. 5, 9 p., accessed February 6, 2016, at http://dx.doi.org/10.1371/journal. ppat. 1000076.

Dusek, R.J., Hallgrimsson, G.T., Ip, H.S., Jónsson, J.E., Sreevatsan, S., Nashold, S.W., TeSlaa, J.L., Enomoto, S., Halpin, R.A., Lin, X., Fedorova, N., Stockwell, T.B., Dugan, V.G., Wentworth, D.E., and Hall, J.S., 2014, North Atlantic migratory bird flyways provide routes for intercontinental movement of avian influenza viruses: PLoS ONE, v. 9, no. 3, 8 p., accessed February 6, 2016, at http://dx.doi. org/10.1371/journal.pone.0092075.

Ellis, D.H., Gee, G.F., Hereford, S.G., Olsen, G.H., Chisolm, T.D., Nicolich, J.M., Sullivan, K.A., Thomas, N.J., Nagendran, M., and Hatfield, J.S., 2000, Post-release survival of hand-reared and parent-reared Mississippi Sandhill Cranes: The Condor, v. 102, no. 1, p. 104-112, accessed February 6, 2016, at http://dx.doi.org/10.1650/00105422(2000)102[0104:PRSOHR]2.0.CO;2. 
Farnsworth, M.L., and Ward, M.P., 2009, Identifying spatiotemporal patterns of transboundary disease spread; Examples using AI H5N1 outbreaks: Veterinary Research, v. 40, no. 3, 14 p., accessed February 6, 2016, at http://dx.doi. org/10.1051/vetres/2009003.

Feng, Z., Baroch, J.A., Long, L-P., Xu, Y., Cunningham, F.L., Pedersen, K., Lutman, M.W., Schmit, B.S., Bowman, A.S., DeLiberto, T.J., and Wan, X-F., 2014, Influenza A subtype H3 viruses in feral swine, United States, 2011-2012: Emerging Infectious Diseases, v. 20, no. 5, p. 843-846, accessed February 6, 2016, at http://dx.doi.org/10.3201/ eid2005.131578.

Ferguson, C., de Roda Husman, A.M., Altavilla, N., Deere, D., and Ashbolt, N., 2003, Fate and transport of surface water pathogens in watersheds: Critical Reviews in Environmental Science and Technology, v. 33, no. 3, p. 299-361, accessed February 6, 2016, at http://dx.doi. org/10.1080/10643380390814497.

Flint, P.L., Ozaki, K., Pearce, J.M., Guzzetti, B., Higuchi, H., Fleskes, J.P., Shimada, T., and Derksen, D.V., 2009, Breeding season sympatry facilitates genetic exchange among allopatric wintering populations of northern pintails in Japan and California: The Condor, v. 111, no. 4, p. 591-598, accessed February 6, 2016, at http://dx.doi.org/10.1525/ cond.2009.090100.

Flint, P.L., Pearce, J.M., Franson, J.C., and Derksen, D.V., 2015, Wild bird surveillance for highly pathogenic avian influenza H5 in North America: Virology Journal, v. 12, no. 151, 6 p., accessed February 6, 2016, at http://dx.doi. org/10.1186/s12985-015-0377-2.

Ford, T.E., Colwell, R.R., Rose, J.B., Morse, S.S., Rogers, D.J., and Yates, T.L., 2009, Using satellite images of environmental changes to predict infectious disease outbreaks: Emerging Infectious Diseases, v. 15, no. 9, p. 1,341-1,346, accessed February 6, 2016, at http://dx.doi.org/10.3201/ $\mathrm{eid} / 1509.081334$.

Francy, D.S., Stelzer, E.A., Brady, A.M.G., Hultger, C., Bushon, R.N., Ip, H.S., Ware, M.W., Villegas, E.N., Gallardo, V., and Lindquist, H.D.A., 2013, Comparison of filters for concentrating microbial indicators and pathogens in lake water samples: Applied and Environmental Microbiology, v. 79, no. 4, p. 1,342-1,352, accessed February 6, 2016, at http://dx.doi.org/10.1128/AEM.03117-12.

Gaidet, N., Cappelle, J., Takekawa, J.Y., Prosser, D.J., Iverson, S.A., Douglas, D.C., Perry, W.M., Mundkur, T., and Newman, S.H., 2010, Potential spread of highly pathogenic avian influenza H5N1 by wildfowl; Dispersal ranges and rates determined from large-scale satellite telemetry: Journal of Applied Ecology, v. 47, p. 1,147-1,157, accessed February 6, 2016, at http://dx.doi.org/10.1111/j.13652664.2010.01845.x.
Gilbert, M., Newman, S.H., Takekawa, J.Y., Loth, L., Biradar, C., Prosser, D.J., Balachandran, S., Subba Rao, M.V., Mundkur, T., Yan, B.P., Xing, Z., Hou, Y.S., Batbayar, N., Natsagdorj, T., Hogerwerf, J.B., Slingenbergh, J., and Xiao, X., 2011, Flying over an infected landscape; Distribution of highly pathogenic avian influenza H5N1 risk in South Asia and satellite tracking of wild waterfowl: EcoHealth, v. 7, no. 4, p. 448-458, accessed February 6, 2016, at http:// dx.doi.org/10.1007/s10393-010-0672-8.

Greene, J.L., 2015, Update on the highly pathogenic avian influenza outbreak of 2014-2015: Congressional Research Service Report R44114, 17 p., accessed February 6, 2016, at https:/www.fas.org/sgp/crs/misc/R44114.pdf.

Gurarie, D., and Seto, E.Y.W., 2009, Connectivity sustains disease transmission in environments with low potential for endemicity; Modelling schistosomiasis with hydrologic and social connectivities: Journal of the Royal Society Interface, v. 6, no. 35, p. 495-508, accessed February 6, 2016, at http://dx.doi.org/10.1098/rsif.2008.0265.

Haack, S.K., Duris, J.W., Kolpin, D.W., Fogarty, L.R., Johnson, H.E., Gibson, K.E., Focazio, M., Schwab, K.J., Hubbard, L.E., and Foreman, W.T., 2015, Genes indicative of zoonotic and swine pathogens are persistent in stream water and sediment following a swine manure spill: Applied and Environmental Microbiology, v. 81, no. 10, p. 3,430-3,441, accessed February 6, 2016, at http://dx.doi.org/10.1128/ aem.04195-14.

Hall, J.S., Bentler, K.T., Landolt, G., Elmore, S.A., Minnis, R.B., Campbell, T.A., Barras, S.C., Root, J.J., Pilon, J., Pabilonia, K., Driscoll, C., Slate, D., Sullivan, H., and McLean, R.G., 2008, Influenza infection in wild raccoons: Emerging Infectious Diseases, v. 14, no. 12, p. 1,842-1,848, accessed February 6, 2016, at http://dx.doi.org/10.3201/ eid1412.071371.

Hall, J.S., Franson, J.C., Gill, R.E., Meteyer, C.U., TeSlaa, J.L., Nashold, S., Dusek, R.J., and Ip, H.S., 2011, Experimental challenge and pathology of highly pathogenic avian influenza virus H5N1 in dunlin (Calidris alpina), an intercontinental migrant shorebird species: Influenza and Other Respiratory Viruses, v. 5, no. 5, p. 365-372, accessed February 6, 2016, at http://dx.doi.org/10.1111/j.17502659.2011.00238.x.

Hall, J.S., Ip, H.S., Franson, J.C., Meteyer, C., Nashold, S., TeSlaa, J.L., French, J., Redig, P., and Brand, C., 2009, Experimental infection of a North American raptor, American kestrel (Falco sparverius), with highly pathogenic avian influenza virus (H5N1): PLoS ONE, v. 4, no. 10, 6 p., accessed February 6, 2016, at http://dx.doi.org/10.1371/ journal.pone.0007555. 
Hall, J.S., Krauss, S., Franson, J.C., TeSlaa, J.L., Nashold, S.W., Stallknecht, D.E., Webby, R.J., and Webster, R.G., 2013, Avian influenza in shorebirds; Experimental infection of ruddy turnstones (Arenaria interpres) with avian influenza virus: Influenza and Other Respiratory Viruses, v. 7 , no. 1, p. 85-92, accessed February 6, 2016, at http://dx.doi. org/10.1111/j.1750-2659.2012.00358.x.

Hall, J.S., Russell, R.E., Franson, J.C., Soos, C., Dusek, R.J., Allen, R.B., Nashold, S.W., TeSlaa, J.L., Jonsson, J.E., Ballard, J.R., Harms, N.J., and Brown, J.D., 2015, Avian influenza ecology in North Atlantic sea ducks; Not all ducks are created equal: PLoS ONE, v. 10, no. 12, 16 p., accessed February 6, 2016, at http://dx.doi.org/10.1371/journal. pone. 0144524 .

Hall, J.S., Ip, H.S., TeSlaa, J.L., Nashold, S.W., and Dusek, R.J., 2016, Experimental challenge of a peridomestic avian species, European Starlings (Sturnus vulgaris), with novel influenza A H7N9 virus from China: Journal of Wildlife Diseases, v. 52, no. 3, p. 709-712, accessed June 22, 2016, at http://dx.doi.org/10.7589/2016-02-033.

Heisey, D.M., Jennelle, C.S., Russell, R.E., and Walsh, D.P., 2014, Using auxiliary information to improve wildlife disease surveillance when infected animals are not detected; A Bayesian approach: PLoS ONE, v. 9, no. 3, 9 p., accessed February 6, 2016, at http://dx.doi.org/10.1371/journal. pone. 0089843 .

Heisey, D.M., Joly, D.O., and Messier, F., 2006, The fitting of general force-of-infection models to wildlife disease prevalence data: Ecology, v. 87, no. 9, p. 2,356-2,365.

Heisey, D.M., Osnas, E.E., Cross, P.C., Joly, D.O., Langenberg, J.A., and Miller, M.W., 2010a, Linking process to pattern; Estimating spatiotemporal dynamics of a wildlife epidemic from cross-sectional data: Ecological Monographs, v. 80, no. 2, p. 221-240, accessed February 6, 2016, at http://dx.doi.org/10.1890/09-0052.1.

Heisey, D.M., Osnas, E.E., Cross, P.C., Joly, D.O., Langenberg, J.A., and Miller, M.W., 2010b, Rejoinder; Sifting through model space: Ecology, v. 91, no. 12, p. 3,503-3,514, accessed February 6, 2016, at http://dx.doi. org/10.1890/10-0894.1.

Henaux, V., Samuel, M.D., and Bunck, C.M., 2010, Modelbased evaluation of highly and low pathogenic avian influenza dynamics in wild birds: PLoS ONE, v. 5, no. 6, 7 p., accessed February 6, 2016, at http://dx.doi.org/10.1371/ journal.pone.0010997.
Hill, N.J., Takekawa, J.Y., Cardona, C.J., Meixell, B.W., Ackerman, J.T., Runstadler, J.A., and Boyce, W.M., 2012, Cross-seasonal patterns of avian influenza virus in breeding and wintering migratory birds; A flyway perspective: Vector-Borne and Zoonotic Diseases, v. 12, no. 3, p. 243-253, accessed April 6, 2016, at http://dx.doi.org/10.1089/ vbz.2010.0246.

Hogerwerf, L., Wallace, R.G., Ottaviani, D., Slingenbergh, J., Prosser, D.J., Bergmann, L., and Gilbert, M., 2010, Persistence of highly pathogenic avian influenza $\mathrm{H} 5 \mathrm{~N} 1$ virus defined by agro-ecological niche: EcoHealth, v. 7, no. 2, p. 213-225, accessed February 6, 2016, at http://dx.doi. org/10.1007/s10393-010-0324-z.

Horimoto, T., and Kawaoka, Y., 2001, Pandemic threat posed by avian influenza A viruses: Clinical Microbiology Reviews, v. 14, no. 1, p. 129-149, accessed February 6, 2016, at http://dx.doi.org/10.1128/CMR.14.1.129-149.2001.

Huang, Y., Li, Y., Burt, D.W., Chen, H., Zhang, Y., Qian, W., Kim, H., Gan, S., Zhao, Y., Li, J., Yi, K., Feng, H., Zhu, P., Li, B., Liu, Q., Fairley, S., Magor, K.E., Du, Z., Hu, X., Goodman, L., Tafer, H., Vignal, A., Lee, T., Kim, K-W., Sheng, Z., An, Y., Searle, S., Herrero, J., Groenen, M.A.M., Crooijmans, R.P.M., Faraut, T., Cai, Q., Webster, R.G., Aldridge, J.R., Warren, W.C., Bartschat, S., Kehr, S., Marz, M., Stadler, P.F., Smith, J., Kraus, R.H.S., Zhao, Y., Ren, L., Fei, J., Morisson, M., Kaiser, P., Griffin, D.K., Rao, M., Pitel, F., Wang, J., and Li, N., 2013, The duck genome and transcriptome provide insight into an avian influenza virus reservoir species: Nature Genetics, v. 45, no. 7, p. 776-783, accessed February 6, 2016, at http://dx.doi.org/10.1038/ ng.2657.

Hubbard, L.E., Spencer, S.K., Borchardt, M.A., Stokdyk, J.P., Firnstahl, A.D., and Kolpin, D.W., 2016, Detection of avian influenza A in groundwater; Results from the 2015 highly pathogenic avian influenza outbreak [abs.]: Abstract for presentation at the 24th Meeting of the Midwest Chapter of the Society of Environmental Toxicology and Chemistry, Madison, Wis., March 14-16, 2016, accessed June 22, 2016, at http://nebula.wsimg.com/66fb018e10721fd189e0a1 e7c1173f23?AccessKeyId=846DC5C5619A06343C74\&dis position $=0$ \&alloworigin $=1$.

Hunt, R.J., Borchardt, M.A., and Bradbury, K.R., 2014, Viruses as groundwater tracers; Using ecohydrology to characterize short travel times in aquifers: Groundwater Rapid Communication, v. 52, no. 2, p. 187-193, accessed February 6, 2016, at http://dx.doi.org/10.1111/gwat.12158.

Hunt, R.J., Borchardt, M.A., Richards, K.D., and Spencer, S.K., 2010, Assessment of sewer source contamination of drinking water wells using tracers and human enteric viruses: Environmental Science \& Technology, v. 44, no. 20, p. 7,956-7,963, accessed February 6, 2016, at http:// dx.doi.org/10.1021/es100698m. 
Huyvaert, K.P., Carlson, J.S., Bentler, K.T., Cobble, K.R., Nolte, D.L., and Franklin, A.B., 2012, Freshwater clams as bioconcentrators of avian influenza virus in water: VectorBorne and Zoonotic Diseases, v. 12, no. 10, p. 904-906, accessed February 6, 2016, at http://dx.doi.org/10.1089/ vbz.2012.0993.

Ip, H.S., Torchetti, M.K., Crespo, R., Kohrs, P., DeBruyn, P., Mansfield, K.G., Baszler, T., Badcoe, L., Bodenstein, B., Shearn-Bochsler, V., Killian, M.L., Pedersen, J.C., Hines, N., Gidlewski, T., Deliberto, T.J., and Sleeman, J.M., 2015, Novel Eurasian highly pathogenic influenza A $\mathrm{H} 5$ viruses in wild birds, Washington, USA, 2014: Emerging Infectious Diseases, v. 21, no. 5, p. 886-890, accessed February 6, 2016, at http://dx.doi.org/10.3201/eid2105.142020.

Jefferies, R.L., 2000, Allochthonous inputs; Integrating population changes and food-web dynamics: Trends in Ecology \& Evolution, v. 15, no. 1, p. 19-22, accessed February 6, 2016, at http://dx.doi.org/10.1016/S0169-5347(99)01758-9.

Jeong, J., Kang, H-M., Lee, E-K., Song, B-M., Kwon, Y-K., Kim, H-R., Choi, K-S., Kim, J-Y., Lee, H-J., Moon, O-K., Jeong, W., Choi, J., Baek, J-H., Joo, Y-S., Park, Y.H., Lee, H-S., and Lee, Y-J., 2014, Highly pathogenic avian influenza virus (H5N8) in domestic poultry and its relationship with migratory birds in South Korea during 2014: Veterinary Microbiology, v. 173, nos. 3-4, p. 249-257, accessed February 6, 2016, at http://dx.doi.org/10.1016/j. vetmic.2014.08.002.

Jones, J.C., Sonnberg, S., Webby, R.J., and Webster, R.G., 2015, Influenza A(H7N9) virus transmission between finches and poultry: Emerging Infectious Diseases, v. 21, no. 4, p. 619-628, accessed February 6, 2016, at http:// dx.doi.org/10.3201/eid2104.141703.

Jones, K.E., Patel, N.G., Levy, M.A., Storeygard, A., Balk, D., Gittleman, J.L., and Daszak, P., 2008, Global trends in emerging infectious diseases: Nature, v. 451, p. 990-993, accessed February 6, 2016, at http://dx.doi.org/10.1038/ nature06536.

Kapczynski, D.R., Pantin-Jackwood, M., Guzman, S.G., Ricardez, Y., Spackman, E., Bertran, K., Suarez, D.L., and Swayne, D.E., 2013, Characterization of the 2012 highly pathogenic avian influenza H7N3 virus isolated from poultry in an outbreak in Mexico; Pathobiology and vaccine protection: Journal of Virology, v. 87, no. 16, p. 9,086-9,096, accessed February 6, 2016, at http://dx.doi.org/10.1128/ JVI.00666-13.
Keawcharoen, J., van Riel, D., van Amerongen, G., Bestebroer, T.M., Beyer, W.E., van Lavieren, R., Osterhaus, A.D.M.E., Fouchier, R.A.M., and Kuiken, T., 2008, Wild ducks as long-distance vectors of highly pathogenic avian influenza virus (H5N1): Emerging Infectious Diseases, v. 14, no. 4, p. 600-607, accessed February 6, 2016, at http://dx.doi.org/10.3201/eid1404.071016.

Keeler, S.P., Dalton, M.S., Cressler, A.M., Berghaus, R.D., and Stallknecht, D.E., 2014, Abiotic factors affecting the persistence of avian influenza virus in surface waters of waterfowl habitats: Applied and Environmental Microbiology, v. 80, no. 9, p. 2,910-2,917, accessed February 6, 2016, at http:// dx.doi.org/10.1128/AEM.03790-13.

Kim, H-R., Kwon, Y-K., Jang, I.I., Lee, Y-J., Kang, H-M., Lee, E-K., Song, B-M, Lee, H-S., Joo Y-S., Lee, K-H., Lee, H-K., Baek, K-H., and Bae, Y-C., 2015, Pathologic changes in wild birds infected with highly pathogenic avian influenza A(H5N8) viruses, South Korea, 2014: Emerging Infectious Diseases, v. 21, no. 5, p. 775-780, accessed February 6,2016 , at http://dx.doi.org/10.3201/eid2105.141967.

Koehler, A.V., Pearce, J.M., Flint, P.L., Franson, J.C., and Ip, H.S., 2008, Genetic evidence of intercontinental dispersal of AI by a migratory bird; The Northern Pintail (Anas acuta): Molecular Ecology, v. 17, no. 21, p. 4,754-4,762, accessed February 6, 2016, at http://dx.doi.org/10.1111/j.1365294x.2008.03953.x.

Kozlowski, C.P., and Hahn, D.C., 2010, Developmental changes in serum androgen levels of Eastern Screech-Owls (Megascops asio): The Wilson Journal of Ornithology, v. 122, no. 4, p. 755-761, accessed February 6, 2016, at http://dx.doi.org/10.1676/10-014.1.

Kuiken, T., 2013, Is low pathogenic avian influenza virus virulent for wild waterbirds?: Proceedings of the Royal Society of London B, Biological Sciences, v. 280, no. 1,763, 11 p., accessed February 6, 2016, at http://dx.doi.org/10.1098/ rspb.2013.0990.

Kurosaki, Y., Magassouba, N.F., Oloniniyi, O.K., Cherif, M.S., Sakabe, S., Takada, A., Hirayama, K., and Yasuda, J., 2016, Development and evaluation of reverse transcriptionloop-mediated isothermal amplification (RT-LAMP) assay coupled with a portable device for rapid diagnosis of Ebola virus disease in Guinea: PLoS Neglected Tropical Diseases, v. 10, no. 2, 12 p., accessed June 15, 2016, at http://dx.doi. org/10.1371/journal.pntd.0004472.

Lang, A.S., Kelly, A., and Runstadler, J.A., 2008, Prevalence and diversity of avian influenza viruses in environmental reservoirs: Journal of General Virology, v. 89, p. 509-519, accessed February 6, 2016, at http://dx.doi.org/10.1099/ vir.0.83369-0. 
Lee, D-H., Torchetti, M.K., Kevin, W., Ip, H.S., Song, C-S., and Swayne, D.E., 2015, Intercontinental spread of Asian-origin $\mathrm{H} 5 \mathrm{~N} 8$ to North America through Beringia by migratory birds: Journal of Virology, v. 89 , no. 12, p. 6,521-6,524, accessed February 6, 2016, at http://dx.doi. org/10.1128/JVI.00728-15.

Lorch, J.M., Muller, L.K., Russell, R.E., O'Connor, M., Lindner, D.L., and Blehert, D.S., 2013, Distribution and environmental persistence of the causative agent of white-nose syndrome, Geomyces destructans, in bat hibernacula of the eastern United States: Applied and Environmental Microbiology, v. 79, no. 4, p. 1,293-1,301, accessed February 6, 2016, at http://dx.doi.org/10.1128/AEM.02939-12.

Lyons, J.E., Runge, M.C., Laskowski, H.P., and Kendall, W.L., 2008, Monitoring in the context of structured decision-making and adaptive management: Journal of Wildlife Management, v. 72 , no. 8 , p. 1,683-1,692, accessed February 6, 2016, at http://dx.doi.org/10.2193/2008-141.

Martin, V., Pfeiffer, D.U., Zhou, X., Xiao, X., Prosser, D.J., Guo, F., and Gilbert, M., 2011, Spatial distribution and risk factors of highly pathogenic avian influenza (HPAI) H5N1 in China: PloS Pathogens, v. 7, no. 3, 11 p., accessed February 6, 2016, at http://dx.doi.org/10.1371/journal. ppat. 1001308.

McClintock, B.T., Nichols, J.D., Bailey, L.L., MacKenzie, D.I., Kendall, W.L., and Franklin, A.B., 2011, Seeking a second opinion; Uncertainty in disease ecology: Ecology Letters, v. 13, no. 6, p. 659-674, accessed February 6, 2016, at http://dx.doi.org/10.1111/j.1461-0248.2010.01472.x.

Meixell, B.W., Borchardt, M.A., and Spencer, S.K., 2013, Accumulation and inactivation of avian influenza virus by the filter-feeding invertebrate, Daphnia magna: Applied and Environmental Microbiology, v. 79, no. 23, p. 7,249-7,255, accessed February 6, 2016, at http://dx.doi.org/10.1128/ AEM.02439-13.

Merkes, C.M., Jackson, C.A., and Amberg, J.J., 2016, Detecting aquatic invasive species among transported fish using a LAMP assay and a portable instrument [abs.]: Abstract for presentation at the 76th Midwest Fish and Wildlife Conference, Grand Rapids, Mich., January 24-27, 2016, accessed February 6, 2016, at https://midwestfishwildlifeconferen2016.sched.org/event $/ 5 \mathrm{dkp} /$ detecting-aquatic-invasivespecies-among-transported-fish-using-a-lamp-assay-and-aportable-instrument.

Millen, H.T., Gonnering, J.C., Berg, R.K., Spencer, S.K., Jokela, W.E., Pearce, J.M., Borchardt, J.S., and Borchardt, M.A., 2012, Glass wool filters for concentrating waterborne viruses and agricultural zoonotic pathogens: Journal of Visualized Experiments, v. 61, accessed February 6, 2016, at http://dx.doi.org/10.3791/3930.
Miller, M.P., Haig, S.M., Mullins, T.D., Ruan, L., Casler, B., Dondua, A., Gates, H.R., Johnson, J.M., Kendall, S., Tomkovich, P.S., Tracy, D., Valchuk, O.P., and Lanctot, R.B., 2015, Intercontinental genetic structure and gene flow in dunlin (Calidris alpina), a potential vector of avian influenza: Evolutionary Applications, v. 8, no. 2, p. 149-171, accessed February 6, 2016, at http://dx.doi.org/ 10.1111/ eva.12239.

Mitchell, M.S., Gude, J.A., Anderson, N.J., Ramsey, J.M., Thompson, M.J., Sullivan, M.G., Edwards, V.L., Gower, C.N., Cochrane, J.F., Irwin, E.R., and Walshe, T., 2013, Using structured decision making to manage disease risk for Montana wildlife: Wildlife Society Bulletin, v. 37, no. 1, p. 107-114, accessed February 6, 2016, at http://dx.doi. org/10.1002/wsb.237.

Morand, S., Owers, K.A., Waret-Szkuta, A., McIntyre, K.M., and Baylis, M., 2013, Climate variability and outbreaks of infectious diseases in Europe: Scientific Reports, v. 3, no. 1,774, 6 p., accessed February 6, 2016, at http://dx.doi. org/10.1038/srep01774.

Newman, S.H., Iverson, S.A., Takekawa, J.Y., Gilbert, M., Prosser, D.J., Batbayar, N., Natsagdorj, T., and Douglas, D.C., 2009, Migration of whooper swans and outbreaks of highly pathogenic avian influenza $\mathrm{H} 5 \mathrm{~N} 1$ virus in eastern Asia: PLoS ONE, v. 4, no. 5, 11 p., accessed February 6, 2016, at http://dx.doi.org/10.1371/journal.pone.0005729.

Palm, E.C., Newman, S.H., Prosser, D.J., Xiao, X., Ze, L., Batbayar, N., Balachandran, S., and Takekawa, J.Y., 2015, Mapping migratory flyways in Asia using dynamic Brownian bridge movement models: Movement Ecology, v. 3, no. 3, 10 p., accessed February 6, 2016, at http://dx.doi. org/10.1186/s40462-015-0029-6.

Pasick, J., Berhane, Y., Embury-Hyatt, C., Copps, J., Kehler, H., Handel, K., Babiuk, S., Hooper-McGrevy, K., Li, Y., Le, Q.M., and Phuong, S.L., 2007, Susceptibility of Canada Geese (Branta canadensis) to highly pathogenic avian influenza virus (H5N1): Emerging Infectious Diseases, v. 13, no. 12, p. 1,821-1,827, accessed February 6, 2016, at http:// dx.doi.org/10.3201/eid1312.070502.

Pearce, J.M., Ramey, A.M., Flint, P.L., Koehler, A.V., Fleskes, J.P., Franson, J.C., Hall, J.S., Derksen, D.V., and Ip, H.S., 2009 , Avian influenza at both ends of a migratory flyway; Characterizing viral genomic diversity to optimize surveillance plans for North America: Evolutionary Applications, v. 2, no. 4, p. 457-468, accessed February 6, 2016, at http:// dx.doi.org/10.1111/j.1752-4571.2009.00071.x. 
Probert, W.J.M., Shea, K., Fonnesbeck, C.J., Runge, M.C., Carpenter, T.E., Dürr, S., Garner, M.G., Harvey, N., Stevenson, M.A., Webb, C.T., Werkman, M., Tildesley, M.J., and Ferrari, M.J., 2015. Decision-making for footand-mouth disease control; Objectives matter: Epidemics, v. 15, p. 10-19, accessed February 6, 2016, at http://dx.doi. org/10.1016/j.epidem.2015.11.002.

Prosser, D.J., Cui, P., Takekawa, J.Y., Tang, M, Hou, Y., Collins, B., Yan, B.P., Hill, N.J., Li, T., Li, Y., Lei, F., Guo, S., Xing, Z., He, Y., Zhou, Y., Douglas, D.C., Perry, W.M., and Newman, S.H., 2011, Wild bird migration across the Qinghai-Tibetan plateau; A transmission route for highly pathogenic H5N1: PLoS ONE, v. 6, no. 3, 14 p., accessed February 6, 2016, at http://dx.doi.org/10.1371/journal. pone. 0017622 .

Prosser, D.J., Hungerford, L.L., Erwin, R.M., Ottinger, M.A., Takekawa, J.Y., and Ellis, E.C., 2013, Mapping risk of avian influenza transmission risk at the interface of domestic poultry and wild birds: Frontiers in Public Health, v. 1, article 28, p. 1-11, accessed February 6, 2016, at http:// dx.doi.org/10.3389/fpubh.2013.00028.

Prosser, D.J., Hungerford, L.L., Erwin, R.M., Ottinger, M.A., Takekawa, J.Y., Newman, S.H., Xiao, X., and Ellis, E.C., 2016, Spatial modeling of wild bird risk factors highly pathogenic $\mathrm{A}(\mathrm{H} 5 \mathrm{~N} 1)$ avian influenza virus transmission: Avian Diseases, v. 60, p. 329-336, accessed July 28, 2016, at http://www.bioone.org/doi/10.1637/11125-050615-Reg.

Prosser, D.J., Laurent, K., and Kodad, Y., 2015, Visualizing models for avian influenza viruses; A Web application tool: U.S. Geological Survey Web page, accessed February 6, 2016, at http://www.pwrc.usgs.gov/ai/. [To view Web page use Google Chrome browser.]

Prosser, D.J., Nagel, J., and Takekawa, J.Y., 2014, Animal migration and risk of spread of viral infections, in Singh, S.K., ed., Viral infections and global change: Hoboken, N.J., Wiley Blackwell, p. 628.

Prosser, D.J., Takekawa, J.Y., Newman, S.H., Yan, B., Douglas, D.C., Hou, Y., Xing, Z., Zhang, D., Li, T., Li, Y., Zhao, D., Perry, W.M., and Palm, E.C., 2009, Satellite-marked waterfowl reveal migratory connection between $\mathrm{H} 5 \mathrm{~N} 1$ outbreak areas in China and Mongolia: Ibis, v. 151, no. 3, p. 568-576, accessed February 6, 2016, at http://dx.doi. org/10.1111/j.1474-919X.2009.00932.x.

Prosser, D.J., Wu, J., Ellis, E.C., Gale, F., Van Boeckel, T.P., Wint, W., Robinson, T., Xiao, X., and Gilbert, M., 2011, Modelling the distribution of chickens, ducks, and geese in China: Agriculture Ecosystems \& Environment, v. 141, nos. 3-4, p. 381-389, accessed February 6, 2016, at http:// dx.doi.org/10.1016/j.agee.2011.04.002.
Ramey, A.M., Walther, P., Link, P., Poulson, R.L., Wilcox, B.R., Newsome, G.M, Spackman, E., Brown, J.D., and Stallknecht, D.E., 2014, Optimizing surveillance for South American origin influenza A viruses along the United States Gulf Coast through genomic characterization of isolates from blue-winged teal (Anas discors): Transboundary and Emerging Diseases, v. 63, no. 2, 9 p., accessed February 6, 2016, at http://dx.doi.org/10.1111/tbed.12244.

Ramey, A.M., Poulson, R.L., González-Reiche, A.S., Wilcox, B.R., Walther, P., Link, P., Carter, D.L., Newsome, G.M., Müller, M.L., Berghaus, R.D., Perez, D.R., Hall, J.S., and Stallknecht, D.E., 2014, Evidence for seasonal patterns in the relative abundance of avian influenza virus subtypes in blue-winged teal (Anas discors): Journal of Wildlife Diseases, v. 50, no. 4, p. 916-922, accessed February 6, 2016, at http://dx.doi.org/10.7589/2013-09-232.

Ramey, A.M., Reeves, A.B., Sonsthagen, S.A., TeSlaa, J.L., Nashold, S., Donnelly, T., Casler, B., and Hall, J.S., 2015, Dispersal of H9N2 influenza A viruses between East Asia and North America by wild birds: Virology, v. 482, p. 79-83, accessed February 6, 2016, at http://dx.doi. org/10.1016/j.virol.2015.03.028.

Ramey, A.M., Reeves, A.B., Poulson, R.L., Wasley, J., Esler, D., and Stallknecht, D.E., 2015, Sampling of sea ducks for influenza A viruses in Alaska during winter provides lack of evidence for epidemiological peak of infection: Journal of Wildlife Diseases, v. 51, no. 4, p. 938-941, accessed February 6, 2016, at http://dx.doi.org/10.7589/2015-03-057.

Reeves, A.B., Pearce, J.M., Ramey, A.M., Ely, C.R., Schmutz, J.A., Flint, P.L., Derksen, D.V., Ip, H.S., and Trust, K.A., 2013, Genomic analysis of avian influenza viruses from waterfowl in western Alaska: Journal of Wildlife Diseases, v. 49, no. 3, p. 600-610, accessed February 6, 2016, at http://dx.doi.org/10.7589/2012-04-108.

Richman, S.E., and Lovvorn, J.R., 2004, Relative foraging value to lesser scaup ducks of native and exotic clams from San Francisco Bay: Ecological Applications, v. 14, no. 4, p. 1217-1231, accessed February 6, 2016, at http://dx.doi. org/10.1890/03-5032.

Rohani, P., Breban, R., Stallknecht, D.E., and Drake, J.M., 2009, Environmental transmission of low pathogenicity avian influenza viruses and its implications for pathogen invasion: Proceedings of the National Academy of Sciences, v. 106, no. 25, p. 10,365-10,369, accessed February 6, 2016, at http://dx.doi.org/10.1073/pnas.0809026106.

Rose, J.B., Epstein, P.R., Lipp, E.K., Sherman, B.H., Bernard, S.M., and Patz, J.A., 2001, Climate variability and change in the United States; Potential impacts on waterand foodborne diseases caused by microbiologic agents: Environmental Health Perspectives, v. 109, supplement 2, p. 211-221. 
Runge, M.C., 2011, An introduction to adaptive management for threatened and endangered species: Journal of Fish and Wildlife Management, v. 2, no. 2, p. 220-233, accessed February 6, 2016, at http://dx.doi.org/10.3996/082011JFWM-045.

Russell, R.E., Royle, J.A., DeSimone, R., Schwartz, M.K., Edwards, V., Pilgrim, K.P., and McKelvey, K.S., 2012 , Estimating abundance of mountain lions from unstructured spatial sampling: The Journal of Wildlife Management v. 76, no. 8, p. 1,551-1,561, accessed February 6, 2016, at http://dx.doi.org/10.1002/jwmg.412.

Russell, R.E., Tinsley, K., Erickson, R.A., Thogmartin, W.E., and Szymanski, J., 2014, Estimating the spatial distribution of wintering little brown bat populations in the eastern United States: Ecology and Evolution, v. 4, no. 19, p. 3,746-3,754, accessed February 6, 2016, at http://dx.doi. org/10.1002/ece3.1215.

Samuel, M.D., Hall, J.S., Brown, J.D., Goldberg, D.R., Ip, H.S., and Baranyuk, V.V., 2015, The dynamics of avian influenza in lesser snow geese; Implications for annual and migratory infection patterns: Ecological Applications, v. 25, no. 7 , p. 1,851-1,859, accessed February 6, 2016, at http:// dx.doi.org/10.1890/14-1820.1.

Shea, K., Tildesley, M.J., Runge, M.C., Fonnesbeck, C.J., and Ferrari, M.J., 2014, Adaptive management and the value of information; Learning via intervention in epidemiology: PLoS Biology, v. 12, no. 10, 11 p., accessed February 6, 2016, at http://dx.doi.org/10.1371/journal. pbio. 1001970.

Smith, G.J.D., Vijaykrishna, D., Bahl, J., Lycett, S.J., Worobey, M., Pybus, O.G., Ma, S.K., Cheung, C.L., Raghwani, J., Bhatt, S., Peiris, J.S.M., Guan, Y., and Rambaut, A., 2009, Origins and evolutionary genomics of the 2009 swine-origin H1N1 influenza A epidemic: Nature, v. 459, p. 1,122-1,125, accessed February 6, 2016, at http://dx.doi. org/10.1038/nature08182.

Stumpf, P., Failing, K., Papp, T., Nazir, J., Böhm, R., and Marschang, R.E., 2010, Accumulation of a low pathogenic avian influenza virus in zebra mussels (Dreissena polymorpha): Avian Diseases, v. 54, no. 4, p. 1,183-1,190, accessed February 6, 2016, at http://dx.doi.org/10.1637/9162-111709Reg.1.

Sun, H., Cunningham, F.L., Harris, J., Xu, Y., Long, L-P., Hanson-Dorr, K., Baroch, J.A., Fioranelli, P., Lutman, M.W., Li, T., Pedersen, K., Schmit, B.S., Cooley, J., Lin, X., Jarman, R.G., DeLiberto, T.J., and Wan, X-F., 2015, Dynamics of virus shedding and antibody responses in influenza A virusinfected feral swine: Journal of General Virology, v. 96, p. 2,569-2,578, accessed February 6, 2016, at http://dx.doi. org/10.1099/jgv.0.000225.
Takekawa, J.Y., Heath, S.R., Douglas, D.C., Perry, W.M., Javed, S., Newman, S.H., Suwal, R.N., Rahmani, A.R., Choudhury, B.C., Prosser, D.J., and Yan, B., 2013, Geographic variation in bar-headed geese Anser indicus; Connectivity of wintering areas and breeding grounds across a broad front: Wildfowl, v. 59, p. 100-125.

Takekawa, J.Y., Newman, S.H., Xiao, X., Prosser, D.J., Spragens, K.A., Palm, E.C., Yan, B., Li, T., Lei, F., Zhao, D., Douglas, D.C., Muzaffar, S.B., and Ji, W., 2010a, Migration of waterfowl in the East Asian flyway and spatial relationship to HPAI H5N1 outbreaks: Avian Diseases, v. 54, supplement 1, p. 466-476, accessed February 6, 2016, at http://dx.doi.org/10.1637/8914-043009-Reg.1.

Takekawa, J.Y., Prosser, D.J., Collins, B.M., Douglas, D.C., Perry, W.M., Yan, B., Ze, L., Hou, Y., Lei, F., Li, T., Li, Y., and Newman, S.H., 2013, Movements of wild ruddy shelducks in the central Asian flyway and their spatial relationship to outbreaks of highly pathogenic avian influenza H5N1: Viruses, v. 5, no. 9, p. 2,129-2,152, accessed February 6, 2016, at http://dx.doi.org/10.3390/v5092129.

Takekawa, J.Y., Prosser, D.J., Newman, S.H., Muzaffar, S.B., Hill, N.J., Yan, B., Xiao, X., Lei, F., Li, T., Schwarzbach, S.E., and Howell, J.A., 2010b, Victims and vectors; Highly pathogenic avian influenza H5N1 and the ecology of wild birds: Avian Biology Research, v. 3, no. 2, p. 51-73, accessed February 6, 2016, at http://dx.doi.org/10.3184/175 $815510 X 12737339356701$.

Tejeda, A.R., Aiello, R., Salomoni, A., Berton, V., Vascellari, M., and Cattoli, G., 2015, Susceptibility to and transmission of H5N1 and H7N1 highly pathogenic avian influenza viruses in bank voles (Myodes glareolus): Veterinary Research, v. 46, no. 51, 11 p., accessed February 6, 2016, at http://dx.doi.org/10.1186/s13567-015-0184-1.

Thogmartin, W.E., Sanders-Reed, C.A., Szymanski, J.A., McKann, P.C., Pruitt, L., King, R.A., Runge, M.C., and Russell, R.E., 2013, White-nose syndrome is likely to extirpate the endangered Indiana bat over large parts of its range: Biological Conservation, v. 160, p. 162-172, accessed February 6, 2016, at http://dx.doi.org/10.1016/j. biocon.2013.01.010.

Tian, H., Zhou, S., Dong, L., Van Boeckel, T.P., Cui, Y., Newman, S.H., Takekawa, J.Y., Prosser, D.J., Xiao, X., Wu, Y., Cazelles, B., Huang, S., Yang, R., Grenfell, B.T., and Xu, B., 2015, Avian influenza H5N1 viral and bird migration networks in Asia: Proceedings of the National Academy of Sciences, v. 112, no. 22, p. 172-177, accessed February 6, 2016, at http://dx.doi.org/10.1073/pnas.1405216112. 
U.S. Department of Agriculture, 2015a, Surveillance plan for highly pathogenic avian influenza in waterfowl in the United States: U.S. Department of Agriculture report, 29 p., accessed August 21, 2015, at http://www.aphis.usda.gov/ animal health/downloads/animal_diseases/ai/2015-hpaisurveillance-plan.pdf.

U.S. Department of Agriculture, 2015b, Early detection and monitoring for avian influenzas of significance in wild birds; A U.S. interagency strategic plan: U.S. Department of Agriculture report, 45 p., accessed August 21, 2015, at http://www.aphis.usda.gov/animal_health/downloads/animal_diseases/ai/wild-bird-strategic-plan.pdf.

U.S. Department of Agriculture, 2015c, Wild bird highly pathogenic avian influenza cases in the United States: U.S. Department of Agriculture report, 5 p. [table], accessed June 23, 2016, at https://www.aphis.usda.gov/wildlife_damage/downloads/WILD\%20BIRD\%20POSITIVE $\% 20$ HIGHLY\%20PATHOGENIC\%20AVIAN\%20INFLUENZA\%20CASES\%20IN\%20THE\%20UNITED\%20 STATES.pdf.

U.S. Department of Agriculture, 2015d, Epidemiologic and other analyses of HPAI-affected poultry flocks; June 15, 2015 report: U.S. Department of Agriculture report, 38 p., accessed December 1, 2015, at https://www.aphis.usda.gov/ animal_health/animal_dis_spec/poultry/downloads/Epidemiologic-Analysis-June-15-2015.pdf.

U.S. Department of Agriculture, 2016, Highly pathogenic avian influenza preparedness and response plan: U.S. Department of Agriculture report, 20 p., accessed June 17, 2016, at https://www.aphis.usda.gov/animal_ health/downloads/animal_diseases/ai/hpai-preparednessand-response-plan-2015.pdf.

Van Boeckel, T.P., Prosser, D.J., Franceschini, G., Biradar, C., Wint, W., Robinson, T., and Gilbert, M., 2011, Modelling the distribution of domestic ducks in monsoon Asia: Agriculture Ecosystems \& Environment, v. 141, nos. 3-4, p. 373-380, accessed February 6, 2016, at http://dx.doi. org/10.1016/j.agee.2011.04.013.

Walsh, D.P., Campa, H., III, Beyer, D.E., Jr., and Winterstein, S.R., 2011, Measurement error and survey design in sightability model development: The Journal of Wildlife Management, v. 75, no. 5, p. 1,228-1,235, accessed February 6, 2016, at http://dx.doi.org/10.1002/jwmg.158.

Walsh, D.P., Dreitz, V.J., and Heisey, D.M., 2014, Integrated survival analysis using an event-time approach in a Bayesian framework: Ecology and Evolution, v. 5, no. 3, p. 769-780, accessed February 6, 2016, at http://dx.doi. org/10.1002/ece3.1399.
Walsh, D.P., and Miller, M.W., 2010, A weighted surveillance approach for detecting chronic wasting disease foci: Journal of Wildlife Diseases, v. 46, no. 1, p. 118-135, accessed February 6, 2016, at http://dx.doi.org/10.7589/0090-355846.1.118.

Walter, W.D., Walsh, D.P., Farnsworth, M.L., Winkleman, D.L., and Miller, M.W., 2011, Soil clay content underlies prion infection odds: Nature Communications, v. 2, no. 200, 6 p., accessed February 6, 2016, at http://dx.doi. org/10.1038/ncomms 1203 .

Webster, R.G., Yakhno, M., Hinshaw, V.S., Bean, W.J., and Murti, K.C., 1978, Intestinal influenza; Replication and characterization of influenza viruses in ducks: Virology, v. 84 , no. 2, p. 268-278, accessed February 6, 2016, at http://dx.doi.org/10.1016/0042-6822(78)90247-7.

Williams, B.K., 2011, Adaptive management of natural resources-Framework and issues: Journal of Environment Management, v. 92, no. 5, p. 1,346-1,353, accessed February 6, 2016, at http://dx.doi.org/10.1016/j.jenvman.2010.10.041.

Williams, B.K., Wingard, G.L., Brewer, Gary, Cloern, J.E., Gelfenbaum, Guy, Jacobson, R.B., Kershner, J.L., McGuire, A.D., Nichols, J.D., Shapiro, C.D., van Riper III, Charles, and White, R.P., 2013, U.S. Geological Survey Ecosystems Science Strategy-Advancing discovery and application through collaboration: U.S. Geological Survey Circular 1383-C, 43 p., accessed February 6, 2016, at http://pubs. usgs.gov/circ/1383c/.

Wilson, H.M., Hall, J.S., Flint, P.L., Franson, J.C., Ely, C.R., Schmutz, J.A. and Samuel, M.D., 2013, High seroprevalence of antibodies to avian influenza viruses among wild waterfowl in Alaska; Implications for surveillance: PLoS One, v. 8, no. 3, 7 p., accessed June 22, 2016, at http:// dx.doi.org/10.1371/journal.pone.0058308.

Yamaguchi, N., Hupp, J.W., Higuchi, H., Flint, P.L., and Pearce, J.M., 2010, Satellite-tracking of Northern Pintail Anas acuta during outbreaks of the H5N1 virus in Japan; Implications for virus spread: Ibis, v. 152, no. 2, p. 262-271, accessed February 6, 2016, at http://dx.doi. org/10.1111/j.1474-919X.2010.01010.x.

Yasué, M., Feare, C.J., Bennun, L., and Fiedler, W., 2006, The epidemiology of H5N1 avian influenza in wild birds; Why we need better ecological data: BioScience, v. 56, no. 11, p. 923-929, accessed February 6, 2016, at http://bioscience. oxfordjournals.org/content/56/11/923.full.

Zinsstag, J., Schelling, E., Waltner-Toews, D., and Tanner, M., 2011, From "one medicine" to "one health" and systemic approaches to health and well-being: Preventive Veterinary Medicine, v. 101, nos. 3-4, p. 148-156, accessed February 6, 2016, at http://dx.doi.org/10.1016/j.prevetmed.2010.07.003. 



\section{Appendixes}

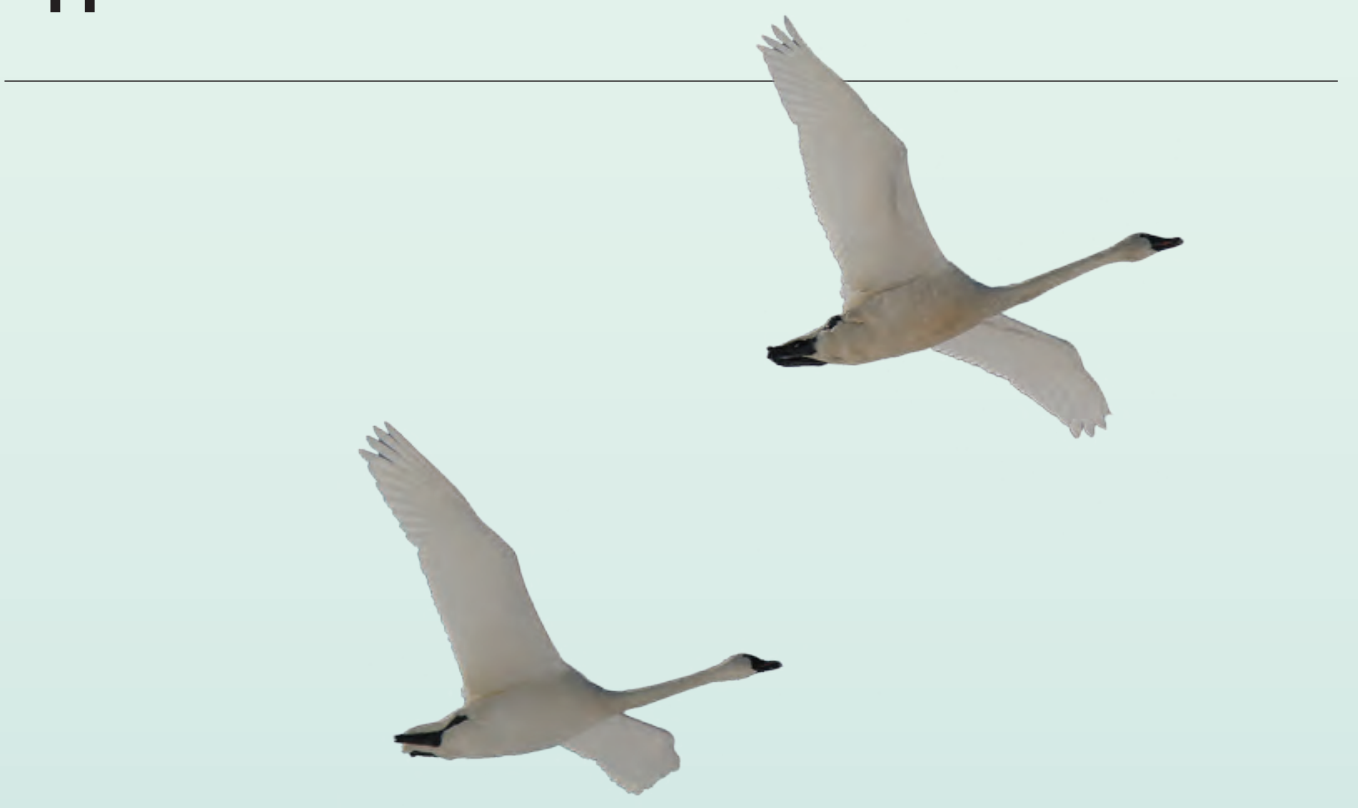




\section{Appendix 1. Overview of U.S. Geological Survey Capabilities for Avian Influenza Research}

The U.S. Geological Survey (USGS) employs over 80 scientists at 9 strategically located Ecosystem Mission Area science centers and 26 Cooperative Research Units (CRUs) that are highly engaged in avian ecological studies. The capabilities of the research centers, located in Alaska, Oregon, California, Arizona, West Virginia, Wisconsin, Maryland, Florida, and Hawaii, are augmented by CRUs co-located at major universities across the contiguous United States. The collective expertise of the USGS is essential to understanding HPAI dynamics in North America (fig. A1-1).

USGS scientists conduct studies on the ecology and migration of multiple avian species across terrestrial and aquatic biomes, which help to determine likely areas of HPAI introduction and optimization of surveillance plans. USGS scientists are addressing questions about long-distance HPAI distribution by migratory birds with bird banding and telemetry (satellite and GPS) data. Subsequently, mathematical models are developed from that movement data to explain observed differences in the spread of the disease across international and U.S. flyways. Genetic and stable isotope techniques are used by USGS scientists to identify long-term population connectivity patterns in migratory birds (see appendix 2). Connectivity data can help elucidate major flight pathways used by sub-populations of individual species as well as interspecific interactions at staging, breeding, and wintering grounds that can influence HPAI spread.

USGS AI studies are conducted in computational, field and laboratory settings and include over two decades of collaborative research in Africa, Europe, Russia, Asia, and North America by scientists from ecosystem research centers across the United States. Unique laboratory investigations are possible because of USGS high biocontainment laboratories (Biosafety Level 3) and wild bird captive research colonies. As the lead Federal agency for wildlife disease surveillance, the USGS maintains the National Wildlife Health Center (NWHC), which supports USDA disease surveillance as part of the National Animal Health Laboratory Network. The NWHC is also an Office International des Epizooties (OIE, World Organization for Animal Health) collaborating center for research, diagnosis, and surveillance of wildlife pathogens.

Disease impacts on ecosystems and species (of management concern) remain a key focus of the USGS. The USGS has expertise in statistical and mathematical modeling of population dynamics, animal movements, resource selection, occupancy dynamics, as well as physical, geospatial, and temporal processes pertinent to HPAI. USGS scientists employ supercomputing and the latest advances in mathematical programming to model infectious disease epidemiology across ecosystems. These models are used to inform biosurveillance and response plans, as well as elucidate effects on host species and ecosystems. Such modeling is important to understand disease risks to wildlife, domestic animals, and humans. Additionally, USGS science can support managers through the use of formal decision-making frameworks (for example, structured decision-making and adaptive management) that can increase the probability of early detection, containment, and successful mitigation of HPAI.

The USGS has the expertise to investigate the distribution and persistence of HPAI viruses in the physical environment (for example, water and sediment) and forecast how changing environmental conditions can affect HPAI dynamics. Similarly, the USGS is well suited to provide the best predictive capability for determining the potential effects of climate change on HPAI dynamics and avian phenology in North America. Strategic coordination of the USGS effort at the national level is recognized as crucial to providing the most effective science useful to resource managers in effectively controlling the disease in wild and domestic environments. Successful implementation of this HPAI science strategy will require integration of HPAI science across USGS mission areas and science centers.

\section{Integrating HPAI Science Across U.S. Geological Survey Mission Areas}

Ecosystems-https://www.usgs.gov/science/mission-areas/ ecosystems

Core Science Systems—https://www.usgs.gov/science/ mission-areas/core-science-systems

Water-https://www.usgs.gov/science/mission-areas/water Environmental Health - https://www.usgs.gov/science/ mission-areas/environmental-health

Climate and Land Use Change- https://www.usgs.gov/

science/mission-areas/climate-and-land-use-change

Natural Hazards - https://www.usgs.gov/science/

mission-areas/natural-hazards

Energy and Minerals-https://www.usgs.gov/science/ mission-areas/energy-and-minerals 


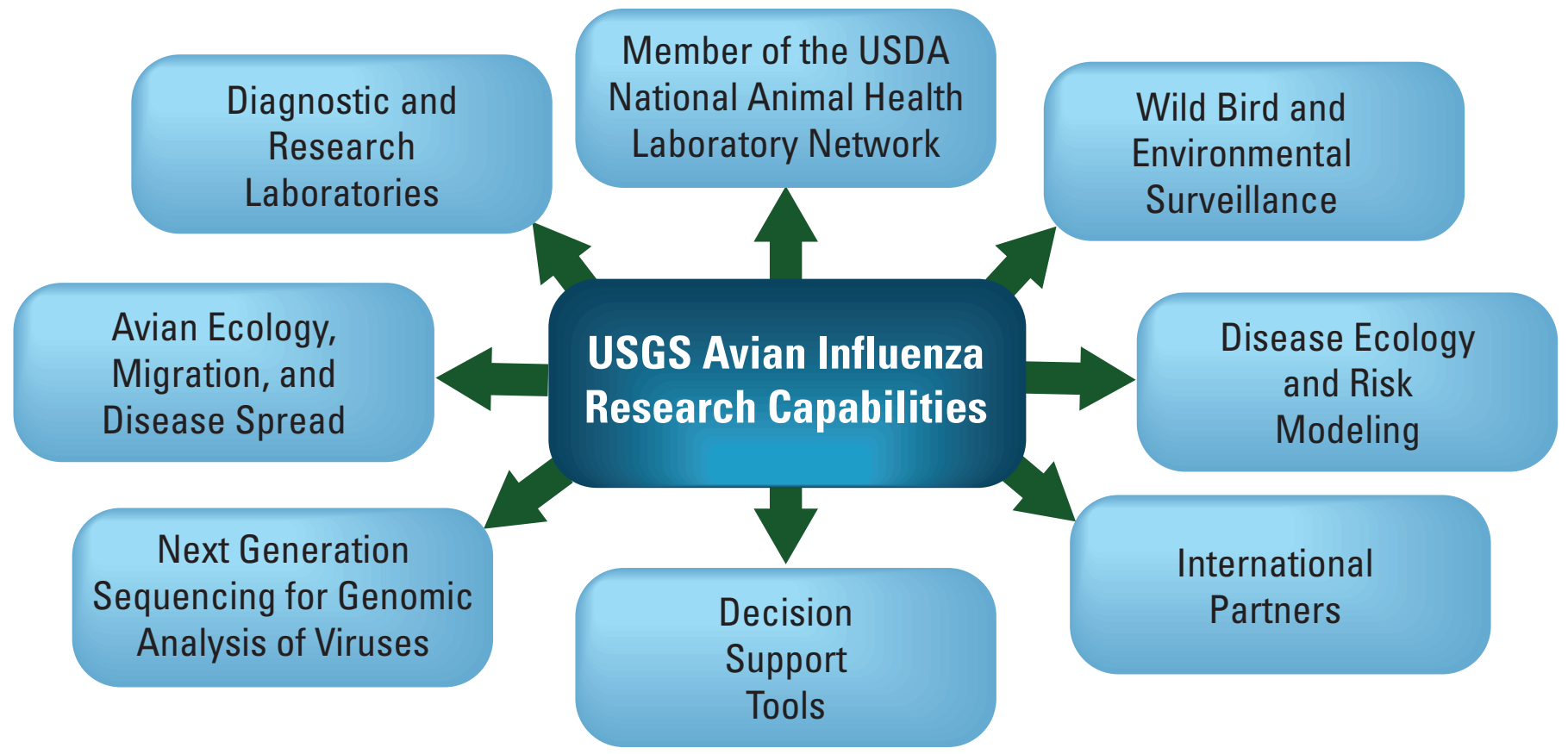

Figure A1-1. Diagram showing the U.S. Geological Survey (USGS) has considerable scientific capabilities nationwide to study avian influenza. Abbreviation: USDA, U.S. Department of Agriculture.

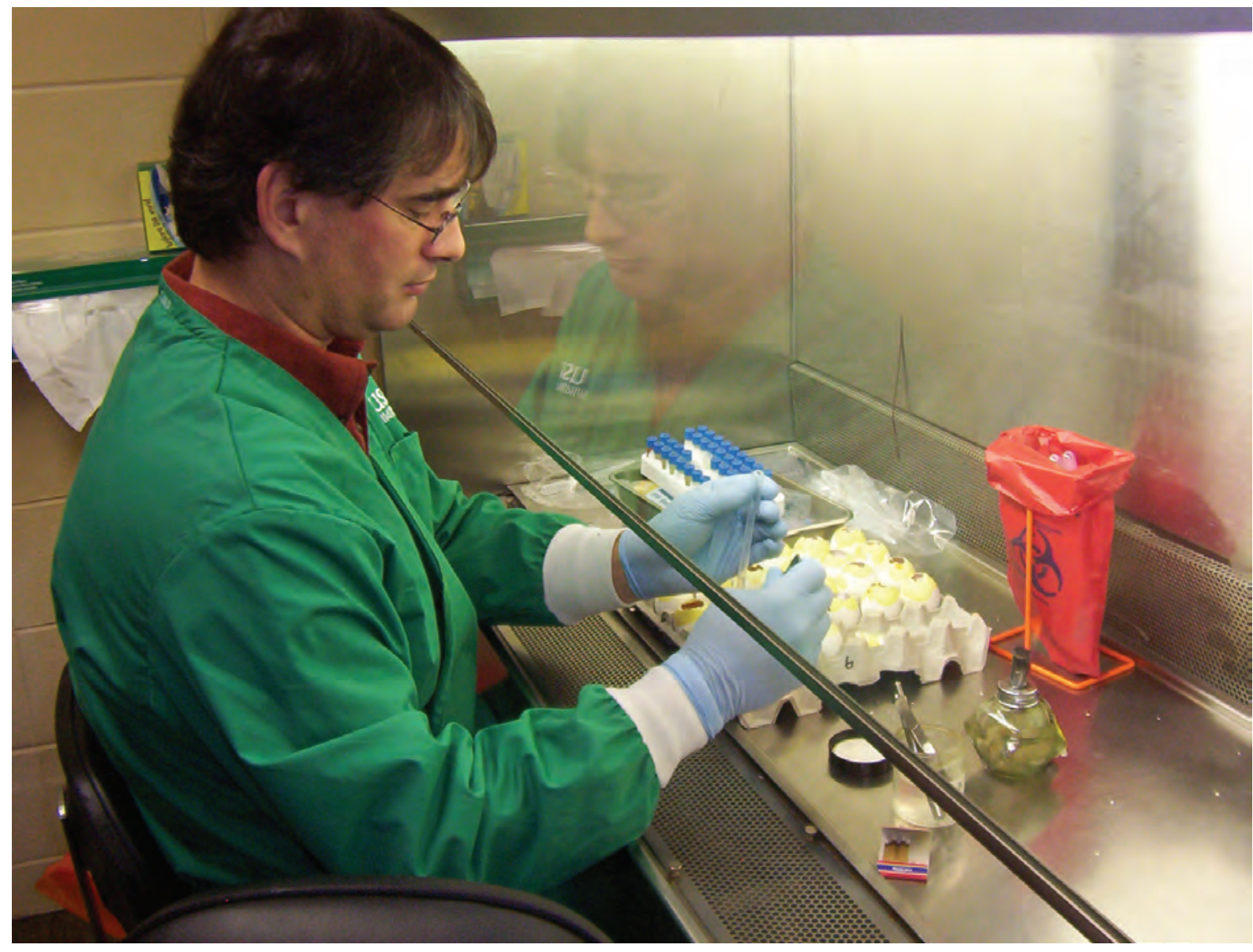

Biological technician Sean Nashold of the U.S. Geological Survey (USGS) National Wildlife Health Center tests chicken eggs inoculated with a field sample from wild birds to detect the presence of avian influenza virus. Photograph by the USGS. 


\section{Appendix 2. Examples of U.S. Geological Survey Capabilities for Avian Influenza Research}

This appendix provides examples of U.S. Geological Survey (USGS) capabilities that will support implementation of the USGS Science Strategy for HPAI in Wildlife and the Environment. A brief description of each capability is followed by descriptions and citations of representative publications.

\section{Genetic and Stable Isotope Analysis of Wildlife Populations}

The USGS has substantial experience researching migratory connectivity patterns in avian populations using genetic markers and stable isotopes. These analyses provide insights about population connectivity and organismal movement, the basis for understanding disease transport dynamics that can facilitate development of more advanced forecasting models.

- ASC and FRESC.-The Alaska Science Center (ASC) and the Forest and Rangeland Ecosystem Science Center (FRESC) are fully equipped with all the instrumentation required to generate genetic and genomic data from avian samples. Laboratory personnel routinely provide blood and tissue sample kits to various groups, and can therefore provide resources to facilitate collection of samples for genetic analyses. The USGS facilities are also capable of long-term storage of blood and tissue samples to preserve valuable genetic samples for future analyses. Examples of representative publications by authors of the ASC and FRESC include Flint and others (2009) and Miller and others (2015).

\section{Telemetry Movement Studies of Wildlife Populations}

The USGS has extensive expertise conducting telemetry and movement studies.

- WERC, ASC, PWRC, and WARC.- - The Western Ecological Research Center (WERC) and the Alaska Research Science Center (ASC) have focused on characterizing migratory movements and connectivity of species that are likely to introduce AI into North America, such as northern pintail ducks. Additionally, the WERC and the Patuxent Wildlife Research Center (PWRC) have developed a partnership with the United Nations Food and Agriculture Organization to study waterfowl movements globally in relation to HPAI H5N1 (>600 marked birds from 12 countries).
These data have been paramount to increasing our understanding of how wild birds might be involved in the spread of HPAI in other regions of the world. The PWRC and the Wetland and Aquatic Research Center (WARC) also have a history of studying waterfowl population ecology and radar ornithology for tracking avian movement over broad spatial scales that would be applicable to understanding the spread of AI. Examples of representative publications include De La Cruz and others (2009), Newman and others (2009), Prosser and other (2009), Gaidet and others (2010), Takekawa and others (2010), Yamaguchi and others (2010), Gilbert and others (2011), Prosser, Cui, and others (2011), Takekawa and others (2013), Prosser and others (2014), and Palm and others (2015).

\section{Disease Risk Modeling}

The USGS has the capacity to model wildlife disease risk including AI transmission risk within wild and domestic bird populations and at this important interface.

- PWRC, WARC, NWHC, UMESC, and NOROCK.-The Patuxent Wildlife Research Center (PWRC) has been working on HPAI H5N1 AI transmission risk for wild and domestic populations since 2005. This research includes building spatial distributions for waterfowl and poultry host species, as well as formulating density-dependent and environmental transmission disease risk models. The PWRC has ties with the U.S. Fish and Wildlife Service (USFWS) Migratory Bird Office and the USDA Economic Research Service and is well-positioned to access and analyze national level waterfowl and poultry data. The Wetland and Aquatic Research Center (WARC) also has experience developing environmentally dependent transmission risk models for wildlife populations. The National Wildlife Health Center (NWHC), Upper Midwest Environmental Sciences Center (UMESC), and Northern Rocky Mountain Science Center (NOROCK) have developed risk models for a variety of wildlife diseases. Examples of representative publications include Almberg and others (2011), Martin and others (2011), Prosser, Wu, and others (2011), Van Boeckel and others (2011), Lorch and others (2013), Prosser and others (2013), Thogmartin and others (2013), and Cappelle and others (2014). 


\section{Statistical and Geospatial Modeling}

The USGS has the capacity to conduct statistical modeling that can be leveraged for most data analysis endeavors.

- WARC, PWRC, NOROCK and NWHC.-The Wetland and Aquatic Research Center (WARC), Patuxent Wildlife Research Center (PWRC), Northern Rocky Mountain Science Center (NOROCK), and National Wildlife Health Center (NWHC) have expertise in statistical modeling of population dynamics, animal movements, resource selection, occupancy dynamics, and spatio-temporal processes. The PWRC has an adaptive management and structured decision-making program, which can be valuable in designing and evaluating epidemiological strategies. Each of these topics will be important to rigorously incorporate data into models for understanding disease dynamics while incorporating uncertainty into predictive results. The WARC and the PWRC also have strong expertise in developing geographic information support tools, which could support the spatial mapping of waterfowl movements in relation to zones of infection and mapping migratory connectivity patterns, as well as quantify uncertainty within the models and their output. Examples of representative publications include Hogerwerf and others (2010), Walsh and others (2011), Cross and others (2012), Russell and others (2012), Russell and others (2014), Walsh and others (2014), and Prosser and others (2015).

\section{Epidemiological Modeling}

The USGS has the capacity to model infectious disease processes including those associated with AI. These models can be used to inform biosurveillance and response plans, as well as elucidate important aspects of a pathogen, its effects on host species and the environment, and overall ecological impact. They are also important in understanding disease risk at the wildlife-livestock interface.

- NWHC, PWRC, NOROCK, and WARC.-The National Wildlife Health Center (NWHC), Patuxent Wildlife Research Center (PWRC), Northern Rocky Mountain Science Center (NOROCK), and Wetland and Aquatic Research Center (WARC) have exploited and developed new statistical techniques for conducting biosurveillance to increase the efficiency of surveillance activities and decrease the effort needed to ascertain disease status at a given statistical confidence level. Examples of representative publications include Heisey and others (2006), Farnsworth and Ward (2009), Heisey and others (2010a), Heisey and others (2010b), Henaux and others (2010), Walsh and Miller (2010), McClintock and others (2011), Walter and others (2011), Cronin and others (2012), Cronin and others (2014), Heisey and others (2014), and Shea and others (2014).

\section{Laboratory and Experimental Animal Studies on Diseases}

The USGS has extensive expertise and capabilities to conduct laboratory wildlife disease research, diagnostics, and field investigations. The USGS has biocontainment facilities dedicated to wildlife disease research.

- NWHC.-The National Wildlife Health Center (NWHC) has Biosafety Level 3 (BSL-3) and Enhanced BSL-3 laboratory and experimental animal isolation facilities. These include personnel, laboratories, and isolation facilities that are certified under the Federal Select Agent Program to work with highly pathogenic AI viruses, which require Enhanced BSL-3 certification from the USDA. Examples of representative publications include Hall and others (2009), Hall and others (2011), and Hall and others (2013).

- PWRC.-The Patuxent Wildlife Research Center (PWRC) maintains captive colonies of sea ducks, kestrels, owls, cranes, and other species, which can be used in experimental studies to better understand the roles of various wildlife species and groups in the epidemiology of AI in wildlife, including species susceptibility, pathogenesis, immunity, viral shedding and transmission, and co-infection dynamics. These variables are important in informing epidemiological, ecological, and predictive and risk models. An on-site veterinarian, animal care staff, and veterinary hospital monitor the health and well-being of these avian colonies. Examples of representative publications include Ellis and others (2000) and Kozlowski and Hahn (2010). 


\section{Decision Science and Data Visualization Tools}

The USGS has the expertise and capabilities to support management agencies through formal decision analyses (structured-decision making and adaptive management). While capabilities have primarily been utilized for management of wildlife species, this capacity has been employed for disease management. The USGS has widespread experience with data visualization tools.

- CIDA and WiM.-The Office of Water Information Center for Integrated Data Analytics (CIDA, http:// cida.usgs.gov/) has extensive experience developing web applications and transactional information systems in support of the USGS and other Federal science initiatives. Wisconsin Internet Mapping (WiM) develops web-based visualization and exploration tools to support USGS science and other Federal initiatives. WiM projects range from full-featured encompassing database and exploration applications to targeted datavisualizations involving specific topic areas.

- NWHC.-The NWHC's Wildlife Health Information Sharing Partnership event reporting system (WHISPers) is an online repository that contains basic information about historic and ongoing wildlife morbidity and mortality events that involve five or more wild animals (https://www.nwhc.usgs.gov/whispers/).

- USGS and CDC Disease Maps.-Dynamic online U.S. maps (http://diseasemaps.usgs.gov/mapviewer/) by the U.S. Geological Survey (USGS) and the Centers for Disease Control and Prevention (CDC) show the occurrence of vector-borne diseases in mosquitoes, birds, veterinary cases, sentinel animals, and humans. Vector-borne viruses visualized include West Nile virus, St. Louis encephalitis virus, eastern equine encephalitis virus, La Crosse encephalitis virus, Powassan virus, Dengue virus, and Chikungunya virus. Examples of representative publications include Lyons and others (2008), Runge (2011), Williams (2011), Mitchell and others (2013), Shea and others (2014), Probert and others (2015).

\section{Virus Detection in the Aquatic Environment}

The USGS scientists have experience sampling for extremely low concentrations of societally-relevant animal and human viruses in the environment. USGS scientists also have experience in virus source and transport studies, including the use of surrogate transport aspects. Specifically, in terms of AI, USGS capabilities include trace-concentration monitoring of the $\mathrm{AI}$ virus in the physical environment.

- WWSC, IWSC and LIDE.-The USGS Water Science Center staff from Wisconsin (WWSC) and Iowa (IWSC) collect and analyze groundwater and surface water samples and are trained in USDA highly pathogenic AI responder methods. The Laboratory for Infectious Disease in the Environment (LIDE), a joint facility of the USGS and USDA Agricultural Research Service, is a Biosafety Level 2+ laboratory equipped to detect trace-concentration levels of AI virus in groundwater and surface water and equipped to identify AI subtypes, including strains responsible for outbreaks. The LIDE detects and quantifies AI virus using a suite of four quantitative polymerase chain reaction (qPCR) assay techniques, including two that were developed by the LIDE for increased sensitivity compared to previously established methods. Use of current AI genetic sequences from recent outbreak strains allows the most sensitive and accurate detection of the virus possible.

The LIDE can also identify other common poultry and agricultural pathogens, zoonotic bacteria, and fecal indicators that provide insights needed to understand virus fate and transport. In addition to detection and quantification, the LIDE uses cell culture methods to determine AI virus infectivity.

The USGS's capabilities and experience for the detection of viruses in the physical environment are located across Mission Areas and Regions, including the Midwest Region's Water and Environmental Health Mission Areas in the Wisconsin and Iowa Water Science Centers, the Ecosystems Mission Area's Alaska Science Center, and in partnership with the USDA through the USGS's LIDE, which is part of the Wisconsin Water Science Center. Examples of representative publications include Hunt and others (2010), Bradford and others (2013), Meixell and others (2013), Abd-Elmaksoud and others (2014), Hunt and others (2014), Haack and others (2015), and Hubbard and others (2016). 
Publishing support provided by the

Reston and Rolla Publishing Service Centers

Edited by David A. Shields

Layout by Suzanne C. Roberts

For more information concerning this report, contact: Anne Kinsinger

USGS Associate Director for Ecosystems

703-648-4050

akinsinger@usgs.gov

M. Camille Harris

USGS Wildlife Disease Coordinator

703-648-4019

mcharris@usgs.gov 
